\title{
Synthesis of monoclinic Celsian from Coal Fly Ash by using a one-step solid-state reaction process
}

\author{
D. Long-González ${ }^{\mathrm{a}}$, J. López-Cuevas ${ }^{\mathrm{a}}$, C.A. Gutiérrez-Chavarría ${ }^{\mathrm{a}}$, P. Pena ${ }^{\mathrm{b}}$, \\ C. Baudin ${ }^{\mathrm{b}}, \mathrm{X}$. Turrillas ${ }^{\mathrm{c}}$ \\ "CINVESTAV-IPN, Unidad Saltillo, Carretera Saltillo-Monterre, Km. 13.5, 25900, Ramos Arizpe, Coahuila, Merico \\ ' Instituto de Cerámica y Vidrio, CSIC, Kelsen S, E-28049 Madrid, Spain \\ "Eduardo Torroja Institute for Construction Sciences, CSIC, Serrano Galvache 4, E-28033 Madrid, Spain
}

\begin{abstract}
Monoclinic (Celsian) and hexagonal (Hexacelsian) $\mathrm{Ba}_{1-x} \mathrm{Sr}_{x} \mathrm{Al}_{2} \mathrm{Si}_{2} \mathrm{O}_{8}$ solid solutions, where $x=0,0.25,0.375,0.5,0.75$ or $\mathrm{l}$, were synthesized by using Coal Fly Ash (CFA) as main raw material, employing a simple one-step solid-state reaction process involving thermal treatment for $5 \mathrm{~h}$ at $850-1300^{\circ} \mathrm{C}$. Fully monoclinic Celsian was obtained at $1200^{\circ} \mathrm{C} / 5 \mathrm{~h}$, for $\mathrm{SrO}$ contents of $0.25 \leq x \leq 0.75$. However, an optimum SrO level of $0.25 \leq x \leq 0.375$ was recommended for the stabilization of Celsian. These synthesis conditions represent a significant improvement over the higher temperatures, longer times and/or multi-step processes needed to obtain fully monoclinic Celsian, when other raw malcrials are used for this purpose, according to previous literature. These results were atlributed to the role of the chemical and phase conslitution of CFA as well as to a likely mineralizing effect of $\mathrm{CaO}$ and $\mathrm{TiO}_{2}$ present in it, which enhanced the Hexacelsian to Celsian conversion.
\end{abstract}

Keywionds: (A) Powders: solid-state reaction; (B) X-ray methods; (E) Thermal applicalions; Celsian

\section{Introduction}

Due to its high resistance to oxidation and reduction [1], low dielectric constant [2] and low thermal expansion coefficient [3], barium aluminosilicate $\left(\mathrm{BaAl}_{2} \mathrm{Si}_{2} \mathrm{O}_{8} \text {, or } \mathrm{BAS}_{2}\right)^{\prime}$, particularly in its monoclinic form, constitutes an attractive material for the matrix of ceramic composites [4,5], as well as for protective coatings [6], $\mathrm{BaAl}_{2} \mathrm{Si}_{2} \mathrm{O}_{8}$ has three polymorphic forms: monoclinic (usually denominated either as Celsian or as Monocelsian), hexagonal (Hexacelsian) and orthorhombic [3,7]. The melting point of stoichiometric $\mathrm{BaAl}_{2} \mathrm{Si}_{2} \mathrm{O}_{8}$ is $1760^{\circ} \mathrm{C}$. Hexacelsian is the stable phase between 1590 and
$1760{ }^{\circ} \mathrm{C}$, and Celsian is stable below $1590^{\circ} \mathrm{C}$. However, Hexacelsian may exist metastably below the latter temperature due to a sluggish hexagonal to monoclinic conversion [8]. Hexacelsian is an undesirable phase due to its high mean thernal expansion coefficient of $8 \times 10^{-6} /{ }^{\circ} \mathrm{C}\left(300-1000{ }^{\circ} \mathrm{C}\right)$ $[3,9]$, when compared to the value of $2.26 \times 10^{-6} \% \mathrm{C}(20-$ $1000^{\circ} \mathrm{C}$ ) reported for Celsian $[3,10]$. Besides, Hexacelsian transforms into the orthorhombic form at 300 " $\mathrm{C}$, which is accompanied by a volume change of $\sim 3-4 \%$, with a consequent microcracking of the material. Thus, successful employment of $\mathrm{BaAl}_{2} \mathrm{Si}_{2} \mathrm{O}_{8}$ requires a previous stabilization of its monoclinic form. It is well-known that the hexagonal to monoclinic conversion is greatly enhanced by the addition of mineralizers such as $\mathrm{Li}_{2} \mathrm{O}, \mathrm{MgO}, \mathrm{CaO}, \mathrm{NaF}$ and $\mathrm{TiO}_{2}[11,12]$. On the other hand, I.G. Talmy and D.A. Haught, as quoted by Bansal et al. [13], showed that partial substitution of $\mathrm{BaO}$ by $\mathrm{SrO}$ in polycrystalline $\mathrm{BaAl}_{2} \mathrm{Si}_{2} \mathrm{O}_{8}$ facilitates the Hexacelsian to Celsian transformation and, under certain conditions, Hexacelsian may never form.

Generally $\mathrm{BaAl}_{2} \mathrm{Si}_{2} \mathrm{O}_{8}$ is synthesized from stoichiometric mixtures of $\mathrm{Al}_{2} \mathrm{O}_{3}, \mathrm{SiO}_{2}$ and $\mathrm{BaCO}_{3}$ reagent-grade powders. 
However, a variety of other alternative raw materials can also be used for this purpose. among which Coal Fly Ash (CFA) is one of the less frequently employed [14]. CFA is a byproduct of coal-buming power plants, whose main chemical constituents are $\mathrm{SiO}_{2}$ and $\mathrm{Al}_{2} \mathrm{O}_{3}$, and whose main mineralogical components are quartz, mullite $\left(\mathrm{Al}_{6} \mathrm{Si}_{2} \mathrm{O}_{13}\right)$ and a highly reactive amorphous phase [15]. Millions of Tons of CFA are produced all over the world each year, most of which are discarded, with minimum use mainly as additive for Portland cement. As a result, an abundant and cheap potential source of $\mathrm{SiO}_{2}$ and $\mathrm{Al}_{2} \mathrm{O}_{3}$, which is already fine and which does not require to be extracted or mined, is basically wasted.

Thus, this work was focused on the synthesis of Celsian, with and without SrO doping. using CFA as main raw material, with particular attention given to the reaction mechanism, as well as to a likely mineralizing effect of impuricies contained in the CFA on stabilization of the monoclinic phase. It is worth mentioning that Amritphale et al. [14], who are up to now the only researchers to have used CFA as raw material for the synthesis of Celsian $\mathrm{BaAl}_{2} \mathrm{Si}_{2} \mathrm{O}_{8}$-containing ceramics, did not study either the Hexacelsian to Celsian transformation or the effect of SrO doping on the latter transformation in their materials. In fact, the chemical compositions studied by these authors differ greatly from those studied in the present work, in such a way that completely different phase compositions and microstructures were obtained in both cases, and for different intended applications.

A further objective of this work was to develop a relatively low-temperature solid-scate synthesis process which was simpler and of shorter duration than those recommended in previous literature repors [16] for the production of Celsian.

\section{Experimental procedure}

$\mathrm{Ba}_{1-x} \mathrm{Sr}_{x} \mathrm{Al}_{2} \mathrm{Si}_{2} \mathrm{O}_{8}$ solid solutions, where $x=0,0.25,0.375$, $0.5,0.75$ or 1 . were synthesized by using a simple one-step solid-state reaction process, employing suitable mixtures of Coal Fly Ash (CFA), $\mathrm{BaCO}_{3}$ (purity of 99.43 wt.\%. Alkem, México). $\mathrm{SrCO}_{3}$ (purity of 97.86 wt.\%, Solvay. México) and $\mathrm{Al}_{2} \mathrm{O}_{3}$ (HPA-0.5. purity of 99.99 wt. \%. Sasol, USA). Monoclinic and hexagonal solid solutions. with $\mathrm{SrO}$ contents in the range of $0.25 \leq x \leq 0.75$, are hereinafuer denominated as Celsian and Hexacelsian, respectively. The limiting compositions with monoclinic structure are denominated as Ba-Celsian $\mathrm{BaAl}_{2} \mathrm{Si}_{2} \mathrm{O}_{8}$, for $x=0$, and $\mathrm{Sr}$-Celsian $\mathrm{SrAl}_{2} \mathrm{Si}_{2} \mathrm{O}_{8}$, for $x=1$.

CFA was collected directly from the cyclone precipitators of "José López Portillo" power plant located in the city of Nava,
Table 1

Mean paricle size of raw mulerials.

\begin{tabular}{ll}
\hline Raw malerials & Paricle size $(\mu \mathrm{m})$ \\
\hline $\mathrm{CFA}$ & 63 (as-received), 5 (after ball milling) \\
$\mathrm{Al}_{2} \mathrm{O}_{3}$ & $<1$ \\
$\mathrm{BaCO}_{3}$ & 3 \\
$\mathrm{SrCO}_{3}$ & 4 \\
\hline
\end{tabular}

Coahuila, México. Then, the CFA was beneficiated in order to eliminate as much $\mathrm{Fe}_{2} \mathrm{O}_{3}$ as possible. For this, the CFA was first sieved using a $125 \mu \mathrm{m}$ mesh. Then. the sieved CFA was ball milled for $5 \mathrm{~h}$ in order to liberate the $\mathrm{Fe}_{2} \mathrm{O}_{3}$ embedded in some of the CFA particles. Subsequently, the milled material was subjected to manual wet magnetic separation using a powerful neodymium magnet. The CFA was analyzed by X-ray fluorescence (Bruker AXS S4 Pioneer XRF, Saltillo, México), $X$-ray diffraction (Philips X'PERT XRD 3040, CuK $\mathrm{K}_{\alpha}$ radiation, Saltillo, México), scanning electron microscopy (Philips XL30 ESEM. Saltillo, México) and simultaneous thermogravimetric and differential thermal analyses TGA/DTA (Perkin Elmer Pyris Diamond 7 apparatus. Pt crucibles and heating rate of $10^{\circ} \mathrm{C} / \mathrm{min}$. Saltillo, México), before and after magnetic separation. The mean particle size of all raw materials was determined by laser diffraction (Coulter LS-100 particle size analyzer, Saltillo. México), see Table 1.

The raw materials were mixed in a two-station Retsch PM200 planetary mill (Saltillo, México) for $1 \mathrm{~h}$ at $350 \mathrm{rpm}$, using agate balls and mortars, and a powder to balls ratio of $1: 2$. The proportions of CFA, $\mathrm{Al}_{2} \mathrm{O}_{3}, \mathrm{BaCO}_{3}$ and $\mathrm{SrCO}_{3}$ in the green powder mixnures prepared are shown in Table 2 .

All green powder mixtures were uniaxially pressed at $95 \mathrm{MPa}$ in order to obtain disks with a diameter of $12 \mathrm{~mm}$ and thickness of $5 \mathrm{~mm}$. These disks were subsequently thermally treated for $5 \mathrm{~h}$ in a Thermolyne 46200 high temperature furnace, in the temperature range of $850-1300{ }^{\circ} \mathrm{C}$, using a heating rate of $5 \mathrm{C} / \mathrm{min}$. After the themal treatment, the furnace was cooled down to room remperature at a cooling rate of $5^{\circ} \mathrm{C} / \mathrm{min}$. A non-compacted and non-chenmally treated powder sample was subjected to simulaneous TGA/DTA studies, under the same conditions used for the CFA, in order to detenmine the decomposition remperature of carbonates. A cross-section of all thermally treaced samples was cut off with diamond saw and flatten out on a lapping plate using $40 \mu \mathrm{m}$ diamond particles, followed by successive grinding steps using 1200 and $2500 \mathrm{SiC}$ grit sizes. A final polish was then given to all samples in successive steps using 6,3 and $1 \mu \mathrm{m}$ diamond

Table 2

Composition of green powder mixtures (wt.\%) with expected crystalline $\mathrm{Ba}_{1-r} \mathrm{Sr}_{r} \mathrm{Al}_{2} \mathrm{Si}_{2} \mathrm{O}_{8}$ after heat treatment.

\begin{tabular}{|c|c|c|c|c|c|}
\hline$X$ & Sample code & CFA & $\mathrm{Al}_{2} \mathrm{O}_{3}$ & $\mathrm{BaCO}_{3}$ & $\mathrm{SrCO}_{3}$ \\
\hline 0 & $\mathrm{BAS}_{2}$ & 42.62 & 13.40 & 44.07 & - \\
\hline 0.25 & $\mathrm{~B} 7 \mathrm{~S} 2$ & 43.78 & 13.76 & 33.99 & 8.46 \\
\hline 0.375 & B6S3 & 44.42 & 13.97 & 28.72 & 12.89 \\
\hline 0.5 & B5S5 & 45.07 & 14.17 & 23.31 & 17.44 \\
\hline 0.75 & $\mathrm{~B} 2 \mathrm{~S} 7$ & 46.44 & 14.60 & 12,00 & 26.95 \\
\hline 1.0 & SAS & 47.87 & 15.07 & - & 37.06 \\
\hline
\end{tabular}


Table 3

Parameters of the departure model used for the refinements. Space Group $C 2 / m$ (no. 12). Cell parameters $a=8.633(6) \AA, b=13.063(8) \AA, c=7.214(5) \AA$. $\beta=115.17(5)^{\circ}$.

\begin{tabular}{|c|c|c|c|c|c|c|c|c|}
\hline Name & Mult. & Wyckoff & $x$ & $y$ & $\bar{z}$ & Uiso & Occ. & Species \\
\hline $\mathrm{Ba}$ & 4 & (i) & 0.28270 & 0.0000 & 0.13057 & 0.0203 & 0.938 & $\mathrm{Ba}$ \\
\hline T1 & 8 & (j) & 0.00832 & 0.18272 & 0.22450 & 0.0167 & 1.00 & Si/Al \\
\hline $\mathbf{T} 2$ & 8 & (j) & 0.20313 & 0.38148 & 0.34697 & 0.0165 & 1.00 & $\mathrm{Si} / \mathrm{Al}$ \\
\hline 01 & 4 & (g) & 0.0000 & 0.1381 & 0.00000 & 0.0192 & 1.00 & 0 \\
\hline $\mathrm{O} 2$ & 4 & (i) & 0.1209 & 0.5000 & 0.28780 & 0.0220 & 1.00 & $\mathrm{O}$ \\
\hline $\mathrm{O} 3$ & 8 & (j) & 0.3266 & 0.3626 & 0.22410 & 0.0259 & 1.00 & $\mathrm{O}$ \\
\hline 04 & 8 & (j) & 0.0251 & 0.3101 & 0.25200 & 0.0250 & 1.00 & 0 \\
\hline 05 & 8 & (j) & 0.1865 & 0.1264 & 0.39700 & 0.0245 & 1.00 & 0 \\
\hline
\end{tabular}

Table 4

Chemical analysis of CFA (wt.\%).

\begin{tabular}{|c|c|c|c|c|c|c|c|c|c|c|}
\hline CFA & $\mathrm{SiO}_{2}$ & $\mathrm{Al}_{2} \mathrm{O}_{3}$ & $\mathrm{Fe}_{2} \mathrm{O}_{3}$ & $\mathrm{CaO}$ & $\mathrm{MgO}$ & $\mathrm{Na}_{2} \mathrm{O}$ & $\mathrm{K}_{2} \mathrm{O}$ & $\mathrm{TiO}_{2}$ & Other oxides ${ }^{a}$ & LOI \\
\hline As-received & 60.33 & 24.93 & 7.13 & 1.97 & 0.52 & 0.59 & 0.69 & 0.60 & 0.85 & 2.38 \\
\hline Beneficiated & 64.59 & 25.73 & 2.57 & 2.12 & 0.48 & 0.46 & 0.37 & 0.59 & 1.11 & 1.94 \\
\hline
\end{tabular}

a $\mathrm{SrO}, \mathrm{ZrO}_{2}, \mathrm{CuO}, \mathrm{NiO}, \mathrm{SO}_{3}$ and $\mathrm{P}_{2} \mathrm{O}_{5}$.

particles on a medium nap cloth. Then the gold-coated surfaces of the samples were examined by SEM, with and without chemical etching ( $5 \mathrm{~s}$ in a 5 vol.\% HF aqueous solution). These samples were also analyzed by XRD after manual grinding using Diamonite mortar and pestle. until a final particle size of $\sim 125 \mu \mathrm{m}$ was achieved. XRD was also used in order to detenmine a semi-quantitative Hexacelsian to Celsian conversion fraction $(f, \%)$, by using the following expression [17]:

$f=\frac{I_{\text {mono }}}{I_{\text {mono }}+I_{\text {hexa }}} \times 100$

where $I_{\text {hexa }}$ and $I_{\text {mono }}$ are the integrated intensities for the (llll 010 reflection of Hexacelsian and for the (130) reflection of Celsian, respectively. JCPDS-files were used to analyze the XRD spectra.

In order to determine the cell parameters and populations of large cations in the synthesized materials, their XRD patterns were fitted by the Pawley and Rietveld methods. For this, a Siemens D5000 XRD apparatus (Karlsruhe. Genmany), equipped with a copper target X-ray nbe, was used. The slits used were: divergence. $2 \mathrm{~mm}$ wide, receiving. $0.2 \mathrm{~mm}$, and detector, $0.6 \mathrm{~mm}$. Diffraction pattenus were collected between $10^{\circ}$ and $70^{\circ}(2 \theta)$ in steps of $0.02^{\circ}(2 \theta)$, counting for $16 \mathrm{~s}$ while specimens were rotated at $15 \mathrm{rmm}$. The Materials Studio 4 (MS4) software package [18] was used for the refinements. The crystal model used as an initial guess was the one published by Skellern et al. [19]. see Table 3. The powders to be analyzed were ground in an agate mortar. placed over a flat glass surface. and uniformly distributed over the surface with the help of a steel blade to diminish preferencial orientations. Finally, the glass sample holder covered with a thin film of Vaseline was tumed over the flat glass surface containing the powders to get a unifonm coat of specimen adhered to the sample holder. Neicher the glass sample holder nor the Vaseline used produced any diffraction signals.
To back up the reaction mechanism proposed. free energy computations for all possible reactions between $\mathrm{BaO} . \mathrm{SiO}_{2}$, $\mathrm{SrO}$ and $\mathrm{Al}_{2} \mathrm{O}_{3}$ were performed using $\mathrm{HSC}$ [20]. This is a computing package that offers an exhaustive thermochemical database and includes enthalpy (H), entropy (S) and heat capacity (C) data for chemical compounds.

\section{Results and discussion}

\subsection{Characterization of CFA}

The chemical compositions of as-received and beneficiated CFA are given in Table 4 . In boch cases, $\mathrm{SiO}_{2}$ and $\mathrm{Al}_{2} \mathrm{O}_{3}$ are the main components of CFA, while iss main impurities are $\mathrm{Fe}_{2} \mathrm{O}_{3}$ and $\mathrm{CaO}$. The combined $\mathrm{SiO}_{2}+\mathrm{Al}_{2} \mathrm{O}_{3}$ content increased from 85.3 to $90.3 \mathrm{wt}$ \% after the beneficiation process. However, while the $\mathrm{Fe}_{2} \mathrm{O}_{3}$ content was reduced in $64.4 \mathrm{wt} . \%$ after this process.

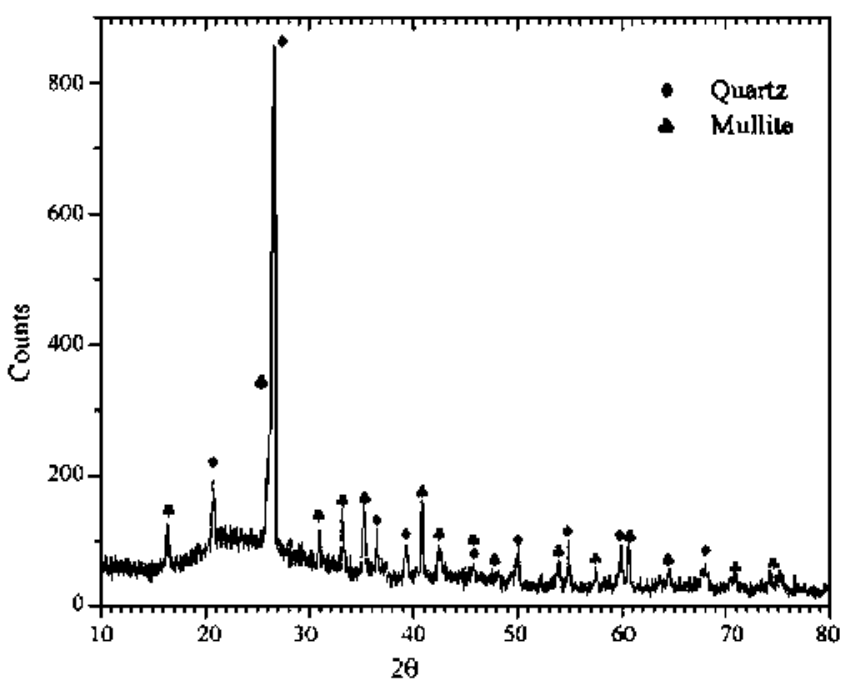

Fig. 1. XRD pattern of beneficiated CFA. 


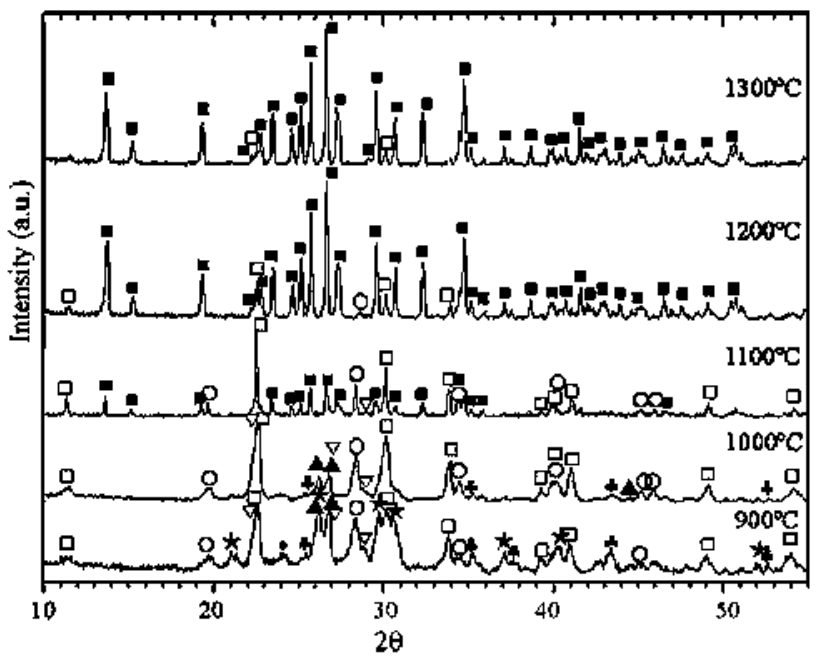

Fig. 2. XRD powdex patterns of BAS nominal composition, heat treated at different temperatures for $5 \mathrm{~h}$. Crystalline phases detected: $\mathrm{C}(\mathbf{Q}), \mathrm{H}(\square), \mathrm{A}$ $(\boldsymbol{\omega}), \mathrm{BA}(\mathrm{O}), \mathrm{BS}(\boldsymbol{\Delta}) \cdot \mathrm{B}_{2} \mathrm{~S}(\star), \mathrm{BS}_{2}(\nabla)$, and $\mathrm{W}(\bullet)$.

that of $\mathrm{CaO}$ remained relatively unchanged in a level close to $2 \mathrm{wt} . \%$. The Loss On lgnition (LOl) of $\sim 2 \mathrm{wt} . \%$ corresponded basically to free carbon present in the CFA. whose level was only slightly reduced by the beneficiation process.

Fig. I shows the XRD pattern of beneficiated CFA. Only quartz and mullite crystalline phases plus a large proportion of amorphous phase were detected. Amorphous phase is visible in the intense broad background (centre: $c a .23^{\circ}, 2 \theta$ ), which is a characteristic feature of this phase.

Dissolution of CFA with HF acid [21,22], followed by ICP chemical analysis of the resulting solution. allowed us to estimate that CFA contains $\sim 75 \mathrm{wt} . \%$ of amorphous phase, with a chemical composition of $74 \mathrm{wt} . \% \mathrm{SiO}_{2}$ and $18 \mathrm{wt} . \%$ $\mathrm{Al}_{2} \mathrm{O}_{3}$ (balance corresponding to $\mathrm{Fe}_{2} \mathrm{O}_{3}, \mathrm{CaO}$. plus other minor impurities). These calculations were carried out assuming that the impurities were basically contained in the glassy phase. Impurities such as $\mathrm{Fe}_{2} \mathrm{O}_{3}$. remaining in the CFA after the beneficiation process, were not detected by XRD because a part of them was present as crystalline phases with a level below the detection limit of the technique employed, while another part was contained in the amorphous phase, also in a low level.

SEM analysis showed that the as-received CFA was composed predominantly by small spherical particles, which were either solid or hollow (cenospheres and plenospheres). Some flake-like particles were also observed.

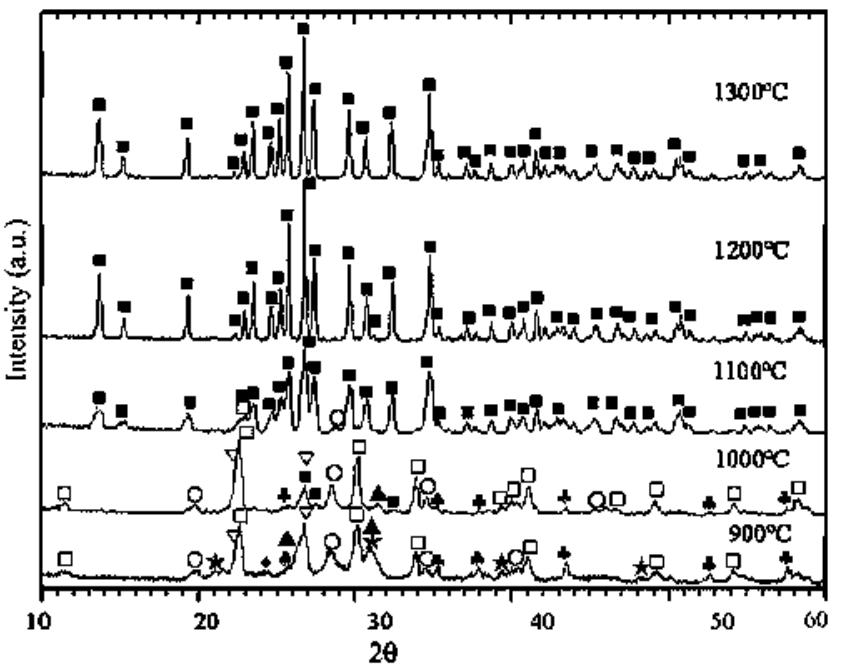

Fig. 3. XRD powder patterns of B7S2 nominal composition. heat treated at different temperalures for $5 \mathrm{~h}$. Crystalline phases detected: $\mathrm{C}(\boldsymbol{\square}) \mathrm{H}(\square), \mathrm{A}$ $(\$), \mathrm{BA}(\mathrm{O}), \mathrm{BS}(\boldsymbol{\Delta}), \mathrm{B}_{2} \mathrm{~S}(\star), \mathrm{BS} \cap(\nabla)$, and $\mathrm{W}(\bullet)$.

\subsection{Characterization of heat-treated samples}

The chemical analyses of heat-treated materials are shown in Table 5. Calculated compositions are given inside the parentheses. Small differences observed between the calculated and the analyzed compositions can be attributed to small errors in sample preparation and chemical analysis, as well as to the presence of impurities in the CFA. However, in all cases the analyzed $\mathrm{SiO}_{2} / \mathrm{Al}_{2} \mathrm{O}_{3}$ and $\mathrm{SiO}_{2} / \mathrm{BaO}$ weight ratios were very close to the theoretical ones.

The phase evolution of the $\mathrm{BAS}_{2}$ and $\mathrm{B} 7 \mathrm{~S} 2$ nominal compositions as a function of temperature can be followed from the XRD patterns shown in Figs. 2 and 3, respectively. The $\mathrm{BAS}_{2}$ material was fully transformed into $\mathrm{BaAl}_{2} \mathrm{Si}_{2} \mathrm{O}_{8}$, mainly in its monoclinic form, after thermally treated at $1300^{\circ} \mathrm{C} / 5 \mathrm{~h}$. On the other hand, the B7S2 nominal composition. Fig. 3. achieved full transformation into monoclinic Celsian at $1200^{\circ} \mathrm{C} / 5 \mathrm{~h}$. The same result was obtained for the B6S3 and B5S5 nominal compositions, according to Table 6 , which gives a summary of the XRD results obtained for all nominal compositions and temperatures studied. In contrast, the B2S7 and SAS nominal compositions achieved a full transfonmation into monoclinic Celsian at $1300^{\circ} \mathrm{C} / 5 \mathrm{~h}$, with the presence of traces of Hexacelsian and strontium aluminate in SAS.

These results indicate that both undoped and SrO-doped monoclinic Celsian can be obtained at relatively low

Table 5

Analyzed chemical composition (wr.\%) of materials with nominal composition of $\mathrm{Ba}_{\mathbf{l}_{x}} \mathrm{Sr}_{x} \mathrm{Al}_{2} \mathrm{Si}_{2} \mathrm{O}_{8}$, after heat treatment at $1200{ }^{\circ} \mathrm{C} / 5 \mathrm{~h}$.

\begin{tabular}{|c|c|c|c|c|c|c|c|c|c|c|c|c|}
\hline$x$ & Sample code & $\mathrm{SiO}_{2}$ & $\mathrm{Al}_{2} \mathrm{O}_{3}$ & $\mathrm{BaO}$ & $\mathrm{SrO}$ & $\mathrm{Fe}_{2} \mathrm{O}_{3}$ & $\mathrm{CaO}$ & $\mathrm{MgO}$ & $\mathrm{Na}_{2} \mathrm{O}$ & $\mathrm{K}_{2} \mathrm{O}$ & $\mathrm{TiO}_{2}$ & Other oxides \\
\hline 0 & $\mathrm{BAS}_{2}$ & 30.46 & 25.85 & 38.87 & 0.32 & 1.25 & 1.31 & 0.18 & 0.38 & 0.55 & 0.55 & 0.26 \\
\hline 0.25 & $\mathrm{~B} 7 \mathrm{~S} 2$ & 31.49 & 26.72 & 30.13 & 6.79 & 1.40 & 1.46 & 0.18 & 0.29 & 0.65 & 0.60 & 0.26 \\
\hline 0.375 & $\mathrm{~B} 653$ & 32.52 & 27.02 & 25.39 & 10.30 & 1.61 & 1.62 & 0.23 & 0.35 & 0.77 & 0.60 & 0.20 \\
\hline 0.5 & B5S5 & 32.48 & 27.55 & 20.72 & 14.00 & 1.61 & 1.55 & 0.26 & 0.38 & 0.68 & 0.58 & 0.15 \\
\hline 0.75 & $\mathrm{~B} 2 \mathrm{~S} 7$ & 33.38 & 28.31 & 10.65 & 21.58 & 2.25 & 1.62 & 0.31 & 0.36 & 0.75 & 0.61 & 0.16 \\
\hline 1.0 & SAS & 34.89 & 29.61 & 0.83 & 30.10 & 1.34 & 1.50 & 0.23 & 0.22 & 0.69 & 0.45 & 0.10 \\
\hline
\end{tabular}


Table 6

Summary of results of XRD analyses of thermally treated samples ${ }^{\mathrm{a}}$.

\begin{tabular}{|c|c|c|c|c|c|c|}
\hline $\begin{array}{l}\text { Treatment } \\
\text { temperature }\left({ }^{\circ} \mathrm{C}\right)\end{array}$ & $\mathrm{BAS}_{2}$ & B7S2 & $\mathrm{B} 6 \mathrm{S3}$ & B5S5 & $\mathrm{B} 2 \mathrm{~S} 7$ & SAS \\
\hline 850 & $\begin{array}{l}\text { A.W,B }{ }_{2} \text { S.BS, } \\
\text { BS, } S_{2} \text {. }\end{array}$ & $\mathrm{A}, \mathrm{B}_{2} \mathrm{~S}_{\mathrm{S}} \mathrm{BS}_{2}, \mathrm{~W}, \mathrm{BS} . \mathrm{H}$ & $* * *$ & $* * *$ & $* * *$ & R.A.M.S $S_{2} S$ \\
\hline 900 & $\begin{array}{l}\mathrm{H}, \mathrm{A}, \mathrm{BA}, \mathrm{BS} \\
\mathrm{B}_{2} \mathrm{~S}, \mathrm{BS}_{2}, \mathrm{~W}^{\mathrm{t}}\end{array}$ & $\mathrm{H}, \mathrm{A}, \mathrm{B}_{2} \mathrm{~S}, \mathrm{BS}_{2}, \mathrm{BA}, \mathrm{BS}, \mathrm{w}^{\mathrm{t}}$ & $\mathrm{H}, \mathrm{A}, \mathrm{BA}, \mathrm{BS}_{2}, \mathrm{BS}$ & $\begin{array}{l}\mathrm{H}, \mathrm{A}, \mathrm{BS}_{2} \\
\mathrm{~B}_{2} \mathrm{~S}, \mathrm{BA}, \mathrm{BS}^{\mathrm{t}}\end{array}$ & $\mathrm{H}, \mathrm{A}, \mathrm{S}_{2} \mathrm{~S}, \mathrm{SS}, \mathrm{SA}^{\prime}$ & $\mathrm{A}, \mathrm{S}_{2} \mathrm{~S}, \mathrm{H}, \mathrm{SS}, \mathrm{SA}, \mathrm{S}_{2} \mathrm{AS}$ \\
\hline 1000 & H.BA,BS $2 . A$ & $\mathrm{H}, \mathrm{A}, \mathrm{BA} . \mathrm{BS}_{2}, \mathrm{C}, \mathrm{BS}^{\mathrm{t}}$ & $\mathrm{H}, \mathrm{A}, \mathrm{C}, \mathrm{BS}_{2}, \mathrm{BA} . \mathrm{BS}$ & $\begin{array}{l}\text { H,C.A.BA, } \\
\text { BS }_{2} \cdot \mathrm{B}_{2} \mathrm{~S}\end{array}$ & $\mathrm{H}, \mathrm{C}, \mathrm{A} . \mathrm{S}_{2} \mathrm{~S}, \mathrm{SA} . \mathrm{SS}$ & SS,S S.A.H. SA.S $S_{2}$ AS \\
\hline 1100 & $\mathrm{H}, \mathrm{C}, \mathrm{BA}, \mathrm{BS}_{2}{ }^{\mathrm{t}}$ & C. $\cdot \mathrm{BA}^{\mathrm{t}} \cdot \mathrm{H}^{\mathrm{t}}$ & $\mathrm{C} . \mathrm{H}^{\mathrm{t}}, \mathrm{BA}^{\mathrm{t}}$ & $\mathrm{C}, \mathrm{H}^{\mathrm{t}}, \mathrm{BA}^{\mathrm{t}}$ & C.SS, $\mathrm{H}^{\mathrm{t}}, \mathrm{SA}^{\mathrm{t}}$ & C,SS,A,SA,H, $\mathrm{S}_{2} \mathrm{AS}, \mathrm{S}_{2} \mathrm{~S}^{\mathbf{t}}$ \\
\hline 1200 & $\mathrm{C}, \mathrm{H}, \mathrm{BA}^{\mathrm{t}}$ & $\mathrm{C}$ & $\mathrm{C}$ & $\mathrm{C}$ & C.SA ${ }^{t}$ & $\mathrm{C}, \mathrm{SA}, \mathrm{S}_{2} \mathrm{AS}^{\prime}, \mathrm{H}^{\prime}$ \\
\hline 1300 & C.H & $\mathrm{C}$ & C & C & C & $\mathrm{C} . \mathrm{H}^{t}, \mathrm{SA}^{\mathrm{t}}$ \\
\hline
\end{tabular}

alation used in Figs. 2 and 3, and Table 6, is: Celsian (C), Hexacelsian ( $\mathrm{H}), \mathrm{Al}_{2} \mathrm{O}_{3}(\mathrm{~A}), \mathrm{BaAl}_{2} \mathrm{O}_{4}(\mathrm{BA}), \mathrm{BaSiO}_{3}\left(\mathrm{BS}_{3}\right), \mathrm{Ba}_{2} \mathrm{SiO}_{4}\left(\mathrm{~B}_{2} \mathrm{~S}\right), \mathrm{BaSi}_{2} \mathrm{O}_{5}\left(\mathrm{BS}_{2}\right), \mathrm{BaCO}_{3}(\mathrm{~W})$, $\mathrm{Sr}_{2} \mathrm{SiO}_{4}\left(\mathrm{~s}_{2} \mathrm{~S}\right), \mathrm{SrSiO}_{3}(\mathrm{sS}), \mathrm{SrAl}_{2} \mathrm{O}_{4}(\mathrm{sA}), \mathrm{Sr}_{2} \mathrm{Al}_{2} \mathrm{SiO}_{3}\left(\mathrm{~s}_{2} \mathrm{AS}\right), \mathrm{Al}_{6} \mathrm{Si}_{2} \mathrm{O}_{13}(\mathrm{M})$, and $\mathrm{SrCO}_{3}(\mathrm{R})$.

Not analyzed. $t=$ irace.

temperatures and short thenmal treatments using a simple onestep process when CFA is employed as the main raw material. In general. doping the $\mathrm{BaAl}_{2} \mathrm{Si}_{2} \mathrm{O}_{8}$ composition with $\mathrm{SrO}$ in the range of $0.25 \leq x \leq 0.75$, resulced in a reduction of $100^{\circ} \mathrm{C}$ in the temperature required for full transformation of Hexacelsian into Celsian. These synthesis conditions represent a significant improvement over the higher temperatures, longer times and/or multi-step processes needed for full conversion when other raw materials (either amorphous or crystalline, and either mineral or reagent-grade) are used for the synthesis of $\mathrm{BaAl}_{2} \mathrm{Si}_{2} \mathrm{O}_{8}$. with or without SrO doping, according to previously published literature, as described below.

Regarding the synchesis of Celsian $\mathrm{BaAl}_{2} \mathrm{Si}_{2} \mathrm{O}_{3}$ without $\mathrm{SrO}$ doping, Moya Corral and Verduch [3] obcained this phase by solid-state reaction of mixnıres of kaolin and $\mathrm{BaCO}_{3}$ at $1350^{\circ} \mathrm{C} / 24 \mathrm{~h}$. Talmy and Haught [23] synthesized the same phase from $\mathrm{BaCO}_{3}, \mathrm{Al}_{2} \mathrm{O}_{3}$ and amorphous $\mathrm{SiO}_{2}$ at $1500^{\circ} \mathrm{C}$ for $\sim 150 \mathrm{~h}$. Bansal et al. [13] obtained full monoclinic $\mathrm{BaAl}_{2} \mathrm{Si}_{2} \mathrm{O}_{8}$ from cold isostatically pressed and sintered $\left(1300^{\circ} \mathrm{C} / 20 \mathrm{~h}\right)$ glass powders. Lastly, Lee and Aswath [16] synthesized Celsian $\mathrm{BaAl}_{2} \mathrm{Si}_{2} \mathrm{O}_{8}$ using a three-step process. with or without the addition of $\mathrm{Li}_{2} \mathrm{O}$. In the first step, $\mathrm{SiO}_{2}$ and $\mathrm{BaCO}_{3}$ were reacted at $1150^{\circ} \mathrm{C} / 4 \mathrm{~h}$ in order to form barium silicace, avoiding in this way the fonmation of barium aluminate. which is much less reactive than barium silicate and, thus, delays the fonmation of Celsian. In the second step, barium silicate was reacted with $\mathrm{Al}_{2} \mathrm{O}_{3}$ at $1200^{\circ} \mathrm{C} / 6 \mathrm{~h}$ in order to form Hexacelsian. In the third step, Hexacelsian was ground, encouraging in this way the formation of monoclinic Celsian nucleus. and then heat treated at $1200-1530^{\circ} \mathrm{C}$ for $4-50 \mathrm{~h}$. in order to promote its conversion into Celsian. Pure Celsian was obtained when ground presynthesized Hexacelsian was doped with $0.4 \mathrm{wt} . \% \mathrm{Li}_{2} \mathrm{O}$. followed by thenmal treatment at $900^{\circ} \mathrm{C} / 4 \mathrm{~h}$.

Regarding the use of $\mathrm{SrO}$ doping for the synthesis of monoclinic $\mathrm{Ba}_{1-x} \mathrm{Sr}_{\lambda} \mathrm{Al}_{2} \mathrm{Si}_{2} \mathrm{O}_{8}$. Fu et al. [17] obtained this phase by solid-state reaction of mixnures of $\mathrm{BaCO}_{3}, \mathrm{SrCO}_{3}, \mathrm{Al}_{2} \mathrm{O}_{3}$ and $\mathrm{SiO}_{2}$ reagent-grade powders. observing an increase in the Hexacelsian to Celsian conversion with increasing SrO content. achieving a maximum conversion of $\sim 40 \%$ for $x=0.375$ after calcination at $950^{\circ} \mathrm{C} / 4 \mathrm{~h}$. which was followed by heat treatment at $1040^{\circ} \mathrm{C} / 4 \mathrm{~h}$. Bansal [24] obtained Celsian with chemical composition of $\mathrm{Ba}_{0.75} \mathrm{Sr}_{0.25} \mathrm{Al}_{2} \mathrm{Si}_{2} \mathrm{O}_{8}$ by solid-state reaction of a suitable mixture of $\mathrm{Al}_{2} \mathrm{O}_{3}, \mathrm{SiO}_{2}, \mathrm{BaCO}_{3}$ and $\mathrm{SrCO}_{3}$ reagent-grade powders. which was first calcined at $\sim 900-910^{\circ} \mathrm{C}$ for $24 \mathrm{~h}$ and then ground, following this by hot pressing at $1300^{\circ} \mathrm{C}$ for $2-3 \mathrm{~h}$ under a pressure of $27.5 \mathrm{MPa}$. Krzmanc et al. [25] synthesized a material with the same composition by solid-state reaction at $1100^{\circ} \mathrm{C} / 12 \mathrm{~h}$, using similar raw materials, obtaining a mixture of Hexacelsian and Monocelsian. in which the first phase predominated. Bansal [26]. on the other hand, was able to achieve full conversion of Hexacelsian into Celsian for a monolithic specimen containing 90 wt. $\% \mathrm{BaAl}_{2} \mathrm{Si}_{2} \mathrm{O}_{8}$ glass and 10 wt. $\% \mathrm{SrAl}_{2} \mathrm{Si}_{2} \mathrm{O}_{8}$ glass, either after hot pressing at $1000^{\circ} \mathrm{C}$ for $10 \mathrm{~min}$ at $13.8 \mathrm{MPa}$, followed by annealing at $1200^{\circ} \mathrm{C} / 2 \mathrm{~h}$, or after hot pressing at $1300^{\circ} \mathrm{C} / 2 \mathrm{~h}$ under $13.8 \mathrm{MPa}$. Lastly, Bansal et al. [13] obcained full monoclinic Celsian from cold isostatically pressed and sintered (above $900^{\circ} \mathrm{C}$ for $20 \mathrm{~h}$ ) $\mathrm{BaAl}_{2} \mathrm{Si}_{2} \mathrm{O}_{8}$ glass powders doped either with 9.87 or with $18.6 \mathrm{wt}$ \% SrO. In Refs. [13,26], the initial glasses were obtained by melting suitable mixtures of $\mathrm{BaCO}_{3}, \mathrm{SrCO}_{3}, \mathrm{Al}_{2} \mathrm{O}_{3}$ and $\mathrm{SiO}_{2}$ reagent-grade powders at temperatures of $\sim 2000-2100^{\circ} \mathrm{C}$.

As for the case of undoped and $\mathrm{SrO}$-doped $\mathrm{BaAl}_{2} \mathrm{Si}_{2} \mathrm{O}_{8}$ compositions, the conditions employed in this work for the synchesis of Celsian SAS represent also a significant improvement over the higher temperatures. longer times and or multi-step processes needed for full conversion of Hexacelsian into Celsian, according to previous literature reports. For instance. Kobayashi and Inagaki [27] obtained full monoclinic Celsian SAS by solid-state reaction of stoichiometric mixtures of kaolin and $\mathrm{SrCO}_{3}$. which were calcined at $800^{\circ} \mathrm{C}$ for several hours, then milled for $\mathrm{I}-20 \mathrm{~h}$ and uniaxially pressed at $98 \mathrm{MPa}$. following this by heat treatment at $1200^{\circ} \mathrm{C} /$ $1 \mathrm{~h}$. On the other hand. Bansal et al. [13] obtained full monoclinic Celsian SAS from cold isoscatically pressed and sintered $\left(1100^{\circ} \mathrm{C} / 20 \mathrm{~h}\right)$ glass powders.

\subsection{Reaction mechanism for the formation of Celsian}

In order to obtain additional information regarding the reaction mechanism for the formation of Celsian. for the case of the $\mathrm{BaAl}_{2} \mathrm{Si}_{2} \mathrm{O}_{8}$ nominal composition studied, TGA/DTA 


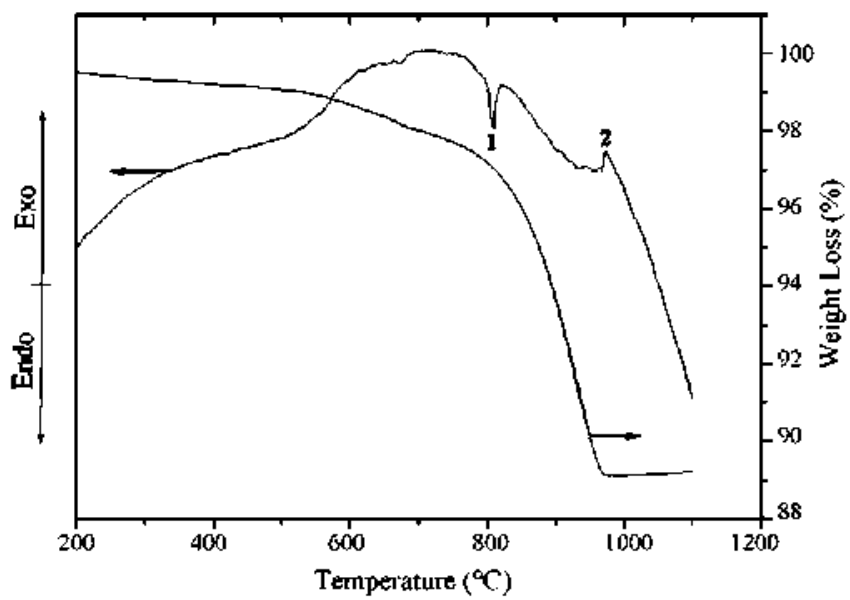

Fig. 4. TGATDTA curves obtained for a green powder mix (ure with the $\mathrm{BAS}_{2}$ nominal composition.

analysis was carried out for the corresponding green powder mixture. Fig. 4 shows the resulss obtained. A weight loss of $\sim 9 \%$ occurring in the TGA curve. in the temperature range of $\sim 675-970^{\circ} \mathrm{C}$, can be attributed to the decomposition of $\mathrm{BaCO}_{3}$, for which a theoretical weight loss of $9.82 \%$ was expected. An endothermic effect observed in the DTA curve, which has a minimum value at $\sim 808^{\circ} \mathrm{C}$ (point 1 ), can be attributed to two different phenomena occurring at very close temperatures: (a) Whiterite $\left(\mathrm{BaCO}_{3}\right) \alpha \leftrightarrows \beta$ polymorphic transformation, and (b) decomposition of $\mathrm{BaCO}_{3}$. The exorhenmic peak at $972{ }^{\circ} \mathrm{C}$ (point 2) was atcributed to crysallization of Hexacelsian. Moya and Verduch [28] obtained similar results for $\mathrm{BaCO}_{3}$ reacting with kaolin. Since it has been reported [29] that thermal decomposition of pure $\mathrm{BaCO}_{3}$ ends at a temperature of $1360^{\circ} \mathrm{C}$, thus, the final decomposition temperature of $\sim 970^{\circ} \mathrm{C}$ determined from the TGA curve was probably associated with the chemical interaction of this carbonate with other components present in the mixture, parricularly $\mathrm{SiO}_{2}$, amorphous phases and mullite, at a relatively low temperature, rather than with its thermal decomposition. This is supported by the fact that the presence of $\mathrm{BaO}$ was not detected by XRD for any of the compositions and treatment temperatures studied.

Maitra and Foger [30] reported that $\mathrm{BaCO}_{3}$ interacts strongly and іпеversibly with $\mathrm{SiO}_{2}$, fonming various barium silicates. These authors found, in derivative TG (DTG) plots that for Ba-rich samples there are two regions of decomposition. The first one, located at $\sim 500^{\circ} \mathrm{C}$. corresponds to the formation of barium silicates, while the second one corresponds to the decomposition of $\mathrm{BaCO}_{3}$. The peak temperature for the latter step tends to decrease with increasing $\mathrm{SiO}_{2}$ concent. In this way, this remperature decreases from $1100^{\circ} \mathrm{C}$ for pure $\mathrm{BaCO}_{3}$ to $1033^{\circ} \mathrm{C}$ for a sample with a $\mathrm{Ba}$ :Si molar ratio of $3: 1$. For samples having a Ba:Si molar ratio of eicher $2: 1$ or $1: 1$, the $\mathrm{BaCO}_{3}$ decomposition peak completely disappears and the DTG plot shows only one peak at $\sim 755-780^{\circ} \mathrm{C}$. corresponding to the formation of barium silicates. It is worth mentioning that these authors also reported that when $\mathrm{BaCO}_{3}$ is mixed with $\mathrm{Al}_{2} \mathrm{O}_{3}$, with a $\mathrm{Ba}: \mathrm{Al}$ molar ratio of $1: 2$, the DTG plot shows also two peaks. one of which is observed just above $800^{\circ} \mathrm{C}$. corresponding to the formation of barium aluminate, and another one corresponding to the decomposition of $\mathrm{BaCO}_{3}$. located at $140^{\circ} \mathrm{C}$ below the peak temperature for the occurrence of the same event in the pure carbonate. They emphasized that. for the case of $\mathrm{BaCO}_{3}-\mathrm{Al}_{2} \mathrm{O}_{3}$ mixnures, the decomposition of unreacted carbonate is always the major event, even for samples containing an excess of alumina.

Table 6 shows, in general, that thenmal treatment at $850^{\circ} \mathrm{C} /$ $5 \mathrm{~h}$ was sufficient to react all quartz and mullite, as well as a part of the amorphous phase contained in the CFA. with part of the added $\mathrm{Al}_{2} \mathrm{O}_{3}$ and with all the $\mathrm{BaO}$ formed by the decomposition of $\mathrm{BaCO}_{3}$. forming various barium silicates and Hexacelsian. without appreciable formation of barium aluminates, which appeared only at temperatures $\geq 900^{\circ} \mathrm{C}$. Lee and Aswath [16] mentioned that by using aluminum silicates as starting materials, the reaction path leading to the formation of Hexacelsian occurs via the initial formation of barium silicates. In this way. Hexacelsian can be fonmed at relatively low temperatures. This agrees with the results obtained from the XRD and TGA/DTA analyses carried out in the present work. The use of CFA as main raw material, which contains $\mathrm{Al}_{2} \mathrm{O}_{3}$ and $\mathrm{SiO}_{2}$ already chemically combined forming mullite and amorphous phases, as well as a large amount of free $\mathrm{SiO}_{2}$ (quartz). facilitated the occurrence of solid-state reactions leading to the initial formation of transient barium silicates instead of barium aluminate, and this in turn led to an easy formation of Hexacelsian, which was subsequently relatively easily transformed into Celsian.

From the XRD and TGA/DTA results obtained, it was deduced that, for the case of the $\mathrm{BaAl}_{2} \mathrm{Si}_{2} \mathrm{O}_{8}$ nominal composition studied, the likely reaction pach was as follows:

(a) The reaction between $\mathrm{BaCO}_{3}$ and silica starts at $T>850^{\circ} \mathrm{C}$ through a series of exothermic reactions. The formation of Ba-silicates as transient phases can be produced by reactions (1)-(6). Reaction (2) has the lowest Gibbs free energy and therefore is the most viable. However, as it is obvious, this reaction does not happen until $\mathrm{BaO}$ is available once $\mathrm{BaCO}_{3}$ decomposes.

$$
\mathrm{BaCO}_{3}+\mathrm{SiO}_{2}=\mathrm{BaSiO}_{3}+\mathrm{CO}_{2} \text {, }
$$

$\Delta G^{900^{\circ} \mathrm{C}}=-19.61 \mathrm{kcal}$

$2 \mathrm{BaCO}_{3}+\mathrm{SiO}_{2}=\mathrm{Ba}_{2} \mathrm{SiO}_{4}+2 \mathrm{CO}_{2}(\mathrm{~g})$,

$\Delta G^{\mathrm{900} 0^{\circ} \mathrm{C}}=-31.12 \mathrm{kcal}$

$\mathrm{BaCO}_{3}+2 \mathrm{SiO}_{2}=\mathrm{BaSi}_{2} \mathrm{O}_{5}+\mathrm{CO}_{2}(\mathrm{~g})$,

$\Delta G^{900^{\circ} \mathrm{C}}=-23.5 \mathrm{kcal}$

$\mathrm{BaSiO}_{3}+\mathrm{BaCO}_{3}=\mathrm{Ba}_{2} \mathrm{SiO}_{4}+\mathrm{CO}_{2}(\mathrm{~g})$,

$\Delta G^{900^{\circ} \mathrm{C}}=-5.35 \mathrm{kcal}$

$2 \mathrm{BaSiO}_{3}+\mathrm{SiO}_{2}=\mathrm{Ba}_{2} \mathrm{Si}_{3} \mathrm{O}_{8}, \quad \Delta G^{900^{\circ} \mathrm{C}}=-5.82 \mathrm{kcal}$ 
$\mathrm{Ba}_{2} \mathrm{Si}_{3} \mathrm{O}_{8}+\mathrm{SiO}_{2}=2 \mathrm{BaSi}_{2} \mathrm{O}_{5}, \quad \Delta G^{900^{\circ} \mathrm{C}}=-1.85 \mathrm{kcal}$

The presence of barium silicates $\left(\mathrm{Ba}_{2} \mathrm{SiO}_{4}, \mathrm{BaSiO}_{3}\right.$ and $\mathrm{BaSi}_{2} \mathrm{O}_{5}$ ) was detected by XRD after themmal treatment of the samples in the remperature range of $850-1000^{\circ} \mathrm{C}$. so a fast reaction between $\mathrm{BaO} / \mathrm{BaCO}_{3}$ and $\mathrm{SiO}_{2}$ for the formation of barium silicates was assumed to occur at these temperatures. Indeed, other researchers [31.32] have stated that $\mathrm{BaSiO}_{3}$ is the first barium silicate to form. $\mathrm{BaSiO}_{3}$ led later on to the formation of both $\mathrm{Ba}_{2} \mathrm{SiO}_{4}$ (reaction (4)) and $\mathrm{BaSi}_{2} \mathrm{O}_{5}$ (reaction (6)) barium silicates. during holding time at this temperature. All quartz contained in the CFA was consumed mainly for the formation of barium silicates (reactions (1)-(3), (5) and (6)). It is worth mentioning that formation of $\mathrm{BaSi}_{2} \mathrm{O}_{5}$ directly from $\mathrm{BaSiO}_{3}$ has not been reported in the literature, thus, although the intermediate $\mathrm{Ba}_{2} \mathrm{Si}_{3} \mathrm{O}_{8}$ barium silicate could be fonmed [31]. probably this compound was not detected by XRD due to a fast rate for reaccions (5) and (6).

(b) Formation of Hexacelsian in the temperature interval 850 $1100^{\circ} \mathrm{C}$ as a metastable phase can take place by the following reactions:

$\mathrm{Al}_{6} \mathrm{Si}_{2} \mathrm{O}_{13}+3 \mathrm{BaCO}_{3}+4 \mathrm{SiO}_{2}=3 \mathrm{BaAl}_{2} \mathrm{Si}_{2} \mathrm{O}_{8}+3 \mathrm{CO}_{2}$, $\Delta G^{900^{\circ} \mathrm{C}}=-103.49 \mathrm{kcal}$

$\mathrm{BaSi}_{2} \mathrm{O}_{5}+\mathrm{Al}_{2} \mathrm{O}_{3}=\mathrm{BaAl}_{2} \mathrm{Si}_{2} \mathrm{O}_{8}, \quad \Delta G^{900 " \mathrm{C}}=-12.05 \mathrm{kcal}$

Thermodynamic calculations indicate that reaction (7) has the lowest Gibbs free energy; hence, it is the most favourable. Similarly, the amorphous phase contained in the CFA was consumed for the formation of Hexacelsian (reaction (9)):

$$
\begin{aligned}
& {\left[m \mathrm{miO}_{2} \cdot n \mathrm{Al}_{2} \mathrm{O}_{3}\right]_{\mathrm{Ammophous}+(m / 2-n) \mathrm{Al}_{2} \mathrm{O}_{3}}} \\
& \quad+(m / 2) \mathrm{BaCO}_{3}=(m / 2) \mathrm{BaAl}_{2} \mathrm{Si}_{2} \mathrm{O}_{8}+(m / 2) \mathrm{CO}_{2}
\end{aligned}
$$

Due to a lack of thenmodynamic data for the amorphous phase contained in the CFA, the Gibbs free energy of reaction (9) could not be calculated. However, since such an amorphous phase is considered to be highly reactive. it is very likely that reaction (9) was thermodynamically favourable.

(c) Between 900 and $1100^{\circ} \mathrm{C}$ formation of Hexacelsian continued via reaction (8), with additional amounts of this phase formed at the expense of the remaining $\mathrm{Al}_{2} \mathrm{O}_{3}$ and some of the barium silicates previously formed (reaction $(10))$ :

$$
\mathrm{BaSi}_{2} \mathrm{O}_{5}+\mathrm{Al}_{2} \mathrm{O}_{3}=\mathrm{BaAl}_{2} \mathrm{Si}_{2} \mathrm{O}_{8}, \quad \Delta G^{1100^{\circ} \mathrm{C}}=-12.6 \mathrm{kcal}
$$

(d) The formation of $\mathrm{BaAl}_{2} \mathrm{O}_{4}$ by reaction of previously formed barium silicates or by direct reaction of $\mathrm{Al}_{2} \mathrm{O}_{3}$ with $\mathrm{BaCO}_{3}$ or $\mathrm{BaO}$ is not thermodynamically viable (reactions
(11)-(13)). Thus, the formation of barium aluminates was probably due to the presence of areas enriched in aluminum and barium in the sample.

$$
\begin{aligned}
& 2 \mathrm{BaSiO}_{3}+\mathrm{Al}_{2} \mathrm{O}_{3}=\mathrm{BaAl}_{2} \mathrm{Si}_{2} \mathrm{O}_{8}+\mathrm{BaAl}_{2} \mathrm{O}_{4}, \\
& \Delta G^{9000^{\circ} \mathrm{C}}=+38.6 \mathrm{kcal} \\
& \mathrm{Ba}_{2} \mathrm{SiO}_{4}+\mathrm{Al}_{2} \mathrm{O}_{3}=\mathrm{BaAl}_{2} \mathrm{O}_{4}+\mathrm{BaSiO}_{3}, \\
& \Delta G^{1100^{\circ} \mathrm{C}}=+40.1 \mathrm{kcal} \\
& \mathrm{BaCO}_{3}+\mathrm{Al}_{2} \mathrm{O}_{3}=\mathrm{BaAl}_{2} \mathrm{O}_{4}+\mathrm{CO}_{2}(\mathrm{~g}) \\
& \Delta G^{900^{\circ} \mathrm{C}}=+24.6 \mathrm{kcal} \\
& \mathrm{BaO}+\mathrm{Al}_{2} \mathrm{O}_{3}=\mathrm{BaAl}_{2} \mathrm{O}_{4}, \quad \Delta G^{900^{\circ} \mathrm{C}}=+5.6 \mathrm{kcal}
\end{aligned}
$$

Lee and Aswath [16] mentioned that once $\mathrm{BaAl}_{2} \mathrm{O}_{4}$ is formed, this compound tends to remain even after thermal treatment at $1530^{\circ} \mathrm{C} / 50 \mathrm{~h}$. due to a pretty low reaction rate of $\mathrm{BaAl}_{2} \mathrm{O}_{4}$ with $\mathrm{SiO}_{2}$ to form Hexacelsian. In this work. traces of barium aluminates were detected on the SEM but not by XRD in samples heat treated at $1300^{\circ} \mathrm{C}$, probably because at this temperature the content of barium aluminates was below the detection limit of the XRD technique employed. This sample shows a homogeneous microstnicture with randomly distributed clusters of Ba-aluminates. No diffusion or reaction within the clusters and the rest of the sample occurred probably because the coarse $\mathrm{Ba}$-aluminates were in equilibrium at local level with Celsian. and thus. it was not possible to eliminate them by heat treatment. However. most of the $\mathrm{BaAl}_{2} \mathrm{O}_{4}$ formed by the mechanism explained above was slowly consumed by reaction (15) in the temperanure range of $900-1300^{\circ} \mathrm{C}$, involving the participation of free crystalline quartz and $\mathrm{SiO}_{2}$ contained in the glassy phase, both of them present in the CFA.

$$
\mathrm{BaAl}_{2} \mathrm{O}_{4}+\mathrm{SiO}_{2}=\mathrm{BaAl}_{2} \mathrm{Si}_{2} \mathrm{O}_{8}, \quad \Delta G^{400{ }^{\circ} \mathrm{C}}=-60.08 \mathrm{kcal}
$$

At $\sim 1300^{\circ} \mathrm{C}$ the last $\mathrm{BaSi}_{2} \mathrm{O}_{5}$ remaining could be also completely consumed by $\mathrm{Al}_{2} \mathrm{O}_{3}$ contained in the remnant glassy phase of the CFA, according to reaction (8).

(e) Lastly, between 1100 and $1300^{\circ} \mathrm{C}$, the Hexacelsian to Celsian conversion continued. in such a way that the latter phase became predominant at $1200^{\circ} \mathrm{C}$. It is worth mentioning that small deviations from the Celsian stoichiometry within the samples could induce the development of small quantities of transitory liquid phases in the vicinity of the eutectic point of the subsystem $\mathrm{BaAl}_{2} \mathrm{Si}_{2} \mathrm{O}_{8}-\mathrm{BaSi}_{2} \mathrm{O}_{5}-\mathrm{SiO}_{2}$ at $1122{ }^{\circ} \mathrm{C}$ [33]. These liquid phases could also enhance the polymorphic transformation of Hexacelsian to Celsian. However, this effect was considered to be small and it was not evaluated.

In the case of the SrO-doped compositions studied, a reaction mechanism similar to that proposed above was probably followed for the formation of $\mathrm{Ba}_{1-x} \mathrm{Sr}_{x} \mathrm{Al}_{2} \mathrm{Si}_{2} \mathrm{O}_{8}$ 
solid solutions with monoclinic structure, i.e., the formation of the same phases took place following a similar sequence for all nominal compositions studied, with or without SrO doping, except for the case of the B2S7 material. for which strontium silicates and aluminate were formed instead of the corresponding barium compounds. This suggests that, at relatively low $\mathrm{SrO}$ concentrations, this oxide participated predominantly in the fonmation of $\mathrm{Ba}_{1-x} \mathrm{Sr}_{2}, \mathrm{Al}_{2} \mathrm{Si}_{2} \mathrm{O}_{8}$ solid solutions, instead of reacting with $\mathrm{SiO}_{2}$ and/or $\mathrm{Al}_{2} \mathrm{O}_{3}$ for the formation of strontium silicates and/or strontium aluminate. However, at $\mathrm{SrO}$ levels of $0.75 \leq x \leq 1$, the fonmation of the latter compounds predominated, at all treatment temperatures employed. Krzmanc et al. [25] obtained similar results for SrO concentrations in the range of $0.6 \leq x \leq 1$.

The most important difference observed between the undoped and $\mathrm{SrO}$-doped Celsian compositions was that in the latter case all reactions started at lower temperatures. In this case, the Hexacelsian to Celsian conversion starced in the temperature range of $900-1000^{\circ} \mathrm{C}$. with an increased proportion of the latter phase with increasing $\mathrm{SrO}$ content at $1000^{\circ} \mathrm{C}$. The proportion of Celsian also increased with increasing temperature for a given $\mathrm{S} \mathrm{O} O$ level, becoming the predominant phase at $1100^{\circ} \mathrm{C}$. At $1200^{\circ} \mathrm{C}$. all the SrO-doped materials were composed entirely of Celsian, except for the B2S7 nominal composition, which contained additional traces of strontium aluminate.

In the case of the $\mathrm{SrAl}_{2} \mathrm{Si}_{2} \mathrm{O}_{8}$ composition, a reaction mechanism similar to that deduced for the $\mathrm{BaAl}_{2} \mathrm{Si}_{2} \mathrm{O}_{8}$ material was also followed, alchough in the case of the first composition the mullite present in the CFA completely disappeared only at $900^{\circ} \mathrm{C}$, probably due to reactions (16) and (17):

$\mathrm{Al}_{6} \mathrm{Si}_{2} \mathrm{O}_{13}+3 \mathrm{SrCO}_{3}+4 \mathrm{SiO}_{2}=3 \mathrm{SrAl}_{2} \mathrm{Si}_{2} \mathrm{O}_{8}+3 \mathrm{CO}_{2}$,

$\Delta G^{900^{\circ} \mathrm{C}}=-103.5 \mathrm{kcal}$

$\mathrm{Al}_{6} \mathrm{Si}_{2} \mathrm{O}_{13}+2 \mathrm{SrSiO}_{3}=2 \mathrm{SrAl}_{2} \mathrm{Si}_{2} \mathrm{O}_{8}+\mathrm{Al}_{2} \mathrm{O}_{3}$,

$\Delta G^{900^{\circ} \mathrm{C}}=-27.6 \mathrm{kcal}$

The formation of metastable $\mathrm{Sr}$-silicates $\left(\mathrm{SrSiO}_{3}, \mathrm{Sr}_{2} \mathrm{SiO}_{4}\right)$ was detected by XRD at $900^{\circ} \mathrm{C}$ (reactions (18) and (19)):

$\mathrm{SrCO}_{3}+\mathrm{SiO}_{2}=\mathrm{SrSiO}_{3}+\mathrm{CO}_{2}(\mathrm{~g}), \quad \Delta G^{900^{\circ} \mathrm{C}}=-20.8 \mathrm{kcal}$

$2 \mathrm{SrCO}_{3}+\mathrm{SiO}_{2}=\mathrm{Sr}_{2} \mathrm{SiO}_{4}+2 \mathrm{CO}_{2}(\mathrm{~g})$,

$\Delta G^{900^{\circ} \mathrm{C}}=-30.9 \mathrm{kcal}$

Another difference observed with respect to the $\mathrm{BaAl}_{2} \mathrm{Si}_{2} \mathrm{O}_{8}$ material was the formation of a strontium aluminosilicate $\left(\mathrm{Sr}_{2} \mathrm{Al}_{2} \mathrm{SiO}_{7}, \mathrm{~s}_{2} \mathrm{AS}\right)$. different in chemical composition to Celsian SAS, additionally to the formation of strontium silicates. strontium aluminate and Hexacelsian occurring at $900^{\circ} \mathrm{C}$ (reactions (20)-(24)). $\mathrm{Sr}_{2} \mathrm{Al}_{2} \mathrm{SiO}_{7}$ disappeared later on at $1200^{\circ} \mathrm{C}$.

$\mathrm{SrO}+\mathrm{Al}_{2} \mathrm{O}_{3}=\mathrm{SrAl}_{2} \mathrm{O}_{4}$

$\mathrm{Sr}_{2} \mathrm{SiO}_{4}+\mathrm{Al}_{2} \mathrm{O}_{3}=\mathrm{Sr}_{2} \mathrm{Al}_{2} \mathrm{SiO}_{7}$
$\mathrm{Sr}_{2} \mathrm{SiO}_{4}+\mathrm{Al}_{2} \mathrm{O}_{3}=\mathrm{SrAl}_{2} \mathrm{O}_{4}+\mathrm{SrSiO}_{3}$

$\mathrm{SrSi}_{2} \mathrm{O}_{5}+\mathrm{Al}_{2} \mathrm{O}_{3}=\mathrm{SrAl}_{2} \mathrm{Si}_{2} \mathrm{O}_{8}$

$2 \mathrm{SrSiO}_{3}+2 \mathrm{Al}_{2} \mathrm{O}_{3}=\mathrm{SrAl}_{2} \mathrm{Si}_{2} \mathrm{O}_{8}+\mathrm{SrAl}_{2} \mathrm{O}_{4}$

The Gibbs free energy of reactions (20)-(24) could not be calculated due to a lack of thermodynamic data for some of the chemical species involved in them. However, since the formation of all their chemical producs were indeed detected by XRD, it can be safely assumed that all of these reactions are thermodynamically favourable at remperatures $\geq 900^{\circ} \mathrm{C}$.

Lastly. Celsian SAS was the predominant phase at $1300^{\circ} \mathrm{C}$. with the presence of only trace amounts of Hexacelsian and strontium aluminate at this temperature.

Although the proposed reaction mechanism can help us to explain the evolution of phases observed in our materials as a function of treatment cemperature, it is worch mentioning that there is also a likely mineralizing effect caused by some of the impurities present in the CFA, particularly $\mathrm{CaO}$ and $\mathrm{TiO}_{2}[12]$, which could promoce an easy stabilization of Celsian at a relatively low temperature. This will be discussed further in the following section.

\subsection{Mineralizing effect of some impurities present in the CFA on the stabilization of Celsian}

Besides the SrO dopant added in order to promote the Hexacelsian to Celsian transfonmation, many of the impurities contained in the CFA, namely $\mathrm{Na}_{2} \mathrm{O}, \mathrm{CaO}, \mathrm{TiO}_{2}, \mathrm{MgO}$ and $\mathrm{K}_{2} \mathrm{O}$, Table 4 , are also known to greatly enhance the kinetics of this conversion. Among these oxides. $\mathrm{CaO}$ and $\mathrm{TiO}_{2}$ are the most important ones in terms of their concentration and mineralizing effect in the materials synthesized in this work.

According to Lee and Aswath [12], both $\mathrm{CaO}$ and $\mathrm{TiO}_{2}$ are more efficient mineralizers than $\mathrm{SrF}_{2}$. These authors established that the minimum treatment temperature required for full conversion of Hexacelsian into Celsian. for a constant dopant addition of $10 \mathrm{~mol} . \%$, is: $\sim 1200^{\circ} \mathrm{C}$ for $\mathrm{CaO}, \sim 1250^{\circ} \mathrm{C}$ for $\mathrm{TiO}_{2}$, and $\sim 1300^{\circ} \mathrm{C}$ for $\mathrm{SrF}_{2}$. On the other hand, the minimum dopant amount required to achieve full conversion at $1250^{\circ} \mathrm{C} /$ $4 \mathrm{~h}$, is: $\sim 2 \mathrm{~mol}$. \% for eicher $\mathrm{CaO}$ or $\mathrm{TiO}_{2}$, and $\sim 12 \mathrm{~mol}$. \% for $\mathrm{SrF}_{2}$. The minimum concentration of $2 \mathrm{~mol} . \%$ is equivalent either to $0.3 \mathrm{wt} . \%$ of $\mathrm{CaO}$ or to $0.43 \mathrm{wt} . \%$ of $\mathrm{TiO}_{2}$. Table 5 shows that in our materials the $\mathrm{CaO}$ concentration varied from 1.31 to $1.62 \mathrm{wt} . \%$, while that of $\mathrm{TiO}_{2}$ varied from 0.45 to $0.61 \mathrm{wt} . \%$. This means that all synchesized materials had a concentration of both impurities above the minimum values required for full stabilization of Celsian. according to Ref. [12]. Thus, in this work, a synergistic mineralizing effect of $\mathrm{CaO}$ and $\mathrm{TiO}_{2}$ present in the CFA, which acted in combination with the SrO dopant added, could account for the observed stabilization of Celsian at relatively low temperatures. This is supported by the SEM/EDS results obtained, which are given in Fig. 5 and Table 7. Points 2 and 3 indicated in the micrographs of Fig. 5 correspond to Celsian $\left(\mathrm{BaAl}_{2} \mathrm{Si}_{2} \mathrm{O}_{8}\right)$ grains containing $\mathrm{Fe}_{2} \mathrm{O}_{3}$. $\mathrm{CaO} . \mathrm{Na}_{2} \mathrm{O}$ and $\mathrm{TiO}_{2}$ as impurities, according to Table 7. On the other hand. points 1 and 4 correspond to elongated needle-like 

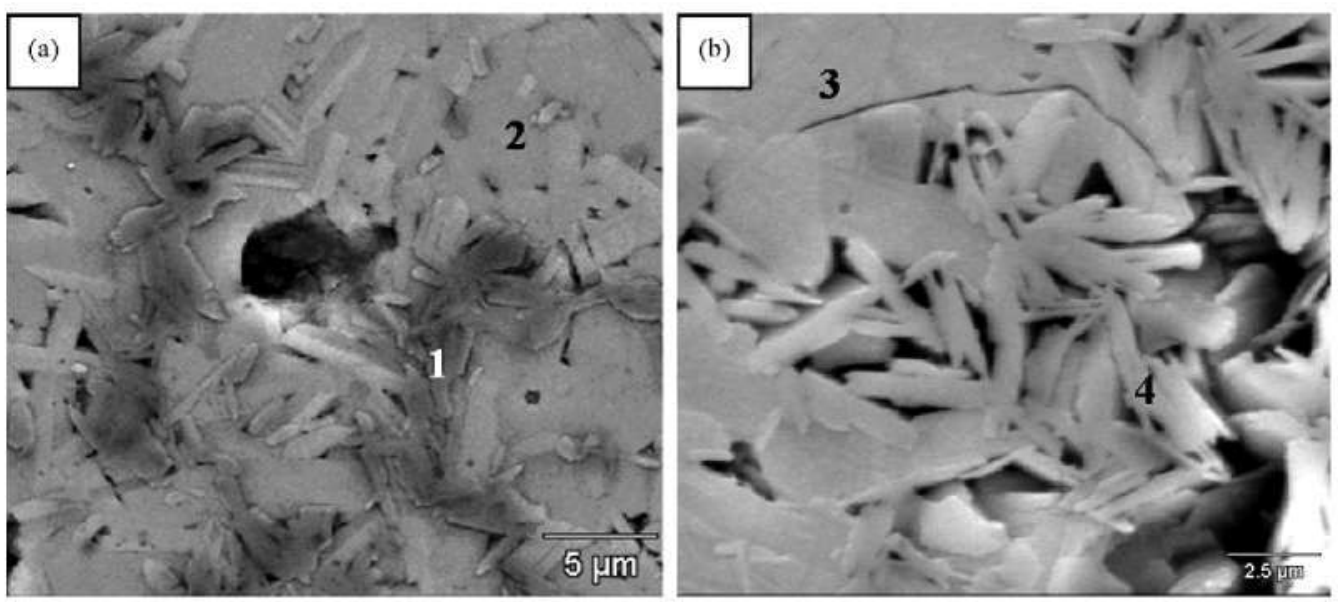

Fig. 5. SEM micrographs of HF-etched $\mathrm{BAS}_{2}$ specimens heat treated at $1300^{\circ} \mathrm{C} / 5 \mathrm{~h}$. (a) Backscattered electrons image, (b) secondary electrons image.
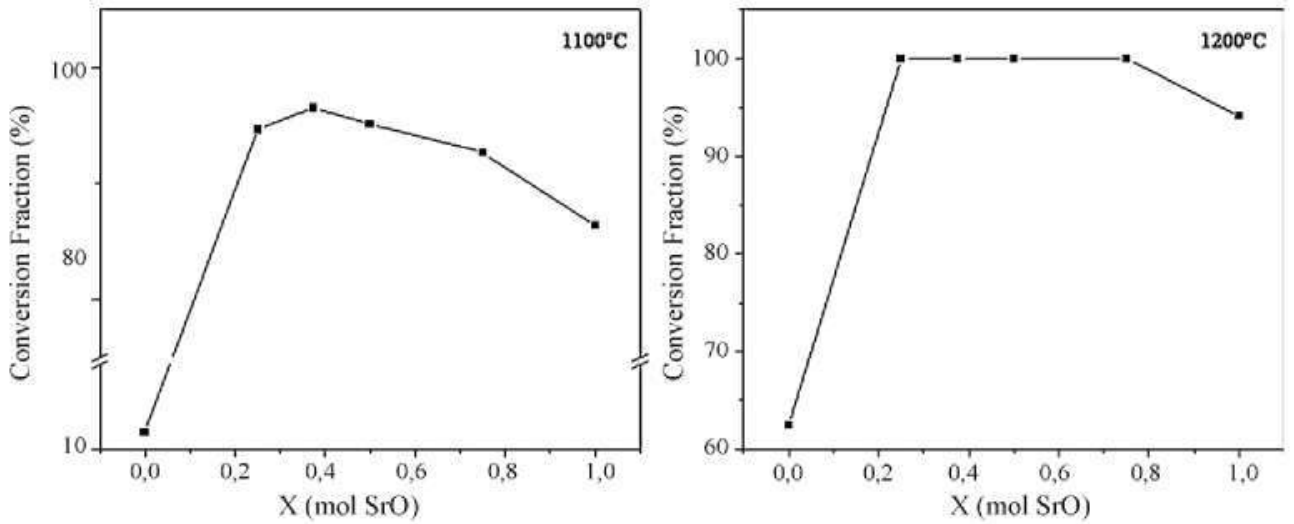

Fig. 6. Hexacelsian to Celsian conversion fraction as a function of $\mathrm{SrO}$ added, after heat treatment at 1100 or $1200{ }^{\circ} \mathrm{C}$ for $5 \mathrm{~h}$.

barium aluminate grains, which contained $\mathrm{Fe}_{2} \mathrm{O}_{3}, \mathrm{MgO}$ and $\mathrm{K}_{2} \mathrm{O}$ as impurities. Thus, the CFA impurities known to have a strong mineralizing effect on the Hexacelsian to Celsian transformation tended to concentrate in the phase with nominal chemical composition of $\mathrm{Ba}_{1-x} \mathrm{Sr}_{x} \mathrm{Al}_{2} \mathrm{Si}_{2} \mathrm{O}_{8}$.

Lee and Aswath [12] mentioned that the addition of mineralizers induces the generation of oxygen and barium vacancies in Hexacelsian, by assisting the braking of its $\mathrm{Ba}-\mathrm{O}$ or $(\mathrm{Al}, \mathrm{Si})-\mathrm{O}$ bonds, and thus promoting in this way its transformation into Celsian. In the case of mineralizers with cationic radii of $\sim 0.99 \AA$, such as $\mathrm{CaO}$, this transformation is likely promoted by formation of an interstitial solid solution in which the $\mathrm{Ca}^{2+}$ cations reside in the double six-ring (D6R) sites of the hexagonal cell, with the consequent creation of $\mathrm{Ba}^{2+}$ vacancies, according to the reaction:

$\mathrm{CaO}=\mathrm{Ca}^{00}+\mathrm{V}_{\mathrm{Ba}}{ }^{n}+\mathrm{O}_{\mathrm{O}}{ }^{\mathrm{X}}+\mathrm{V}^{\mathrm{X}}$
It has also been mentioned [34] that the addition of $\mathrm{CaO}$ enhances the Hexacelsian to Celsian transformation by promoting the formation of Celsian nuclei with a plate-like morphology on the basal planes of the Hexacelsian structure.

In the case of mineralizers with cationic radii of $\sim 0.66 \AA$, such as $\mathrm{TiO}_{2}$, the Hexacelsian to Celsian transformation is likely promoted by substitution of the host $\mathrm{Al}^{3+}\left(\right.$ or $\left.\mathrm{Si}^{4+}\right)$ ions by the guest $\mathrm{Ti}^{4+}$ ions, also with a consequent creation of $\mathrm{Ba}^{2+}$ vacancies, according to the reaction:

$2 \mathrm{TiO}_{2}=2 \mathrm{TiAl}^{\mathrm{O}}+\mathrm{V}_{\mathrm{Ba}}{ }^{\prime \prime}+4 \mathrm{O}_{\mathrm{O}}^{\mathrm{X}}+2 \mathrm{~V}^{\mathrm{X}}$

Lastly, for the case of SrO-doped materials, Lee and Aswath [12] mentioned that the $\mathrm{Sr}^{2+}$ ions could reside in both the $\mathrm{Ba}^{2+}$ host sites and the D6R interstitial sites of Hexacelsian. However, the fact that $\mathrm{Ca}^{2+}$ is a much more efficient dopant than $\mathrm{Sr}^{2+}$ [34], could indicate that the $\mathrm{Sr}^{2+}$ ions reside mainly in the $\mathrm{Ba}^{2+}$-host sites of Hexacelsian.

Table 7

Results of SEM/EDS analyses (wt.\%) carried out in $\mathrm{BAS}_{2}$ specimens of Fig. 5.

\begin{tabular}{lccllllll}
\hline Analyzed point & $\mathrm{SiO}_{2}$ & $\mathrm{Al}_{2} \mathrm{O}_{3}$ & $\mathrm{BaO}$ & $\mathrm{Fe}_{2} \mathrm{O}_{3}$ & $\mathrm{CaO}$ & $\mathrm{Na}_{2} \mathrm{O}$ & $\mathrm{K}_{2} \mathrm{O}$ & $\mathrm{MgO}^{2}$ \\
\hline 1 & 2.41 & 55.74 & 30.26 & 2.69 & & 1.16 & 2.47 & 3.31 \\
2 & 28.8 & 19.59 & 46.78 & 1.17 & & 0.75 & & \\
3 & 30.0 & 21.82 & 46.97 & 0.66 & 0.55 & & 2.91 \\
4 & 2.97 & 64.74 & 16.43 & 9.91 & 0.88 & & 2.4 & 2.66 \\
\hline
\end{tabular}




\subsection{Hexacelsian to Celsian conversion fraction}

According to Fig. 6, a maximum Hexacelsian to Celsian conversion fraction of $\sim 96 \%$ was achieved for $x=0.375$ at $1100^{\circ} \mathrm{C} / 5 \mathrm{~h}$, while full conversion was achieved by doping the $\mathrm{BaAl}_{2} \mathrm{Si}_{2} \mathrm{O}_{8}$ composition with $\mathrm{SrO}$ in the range of $0.25 \leq x \leq 0.75$ at $1200^{\circ} \mathrm{C} / 5 \mathrm{~h}$. As already mentioned, these conversion levels are much higher than those reported by $\mathrm{Fu}$ et al. [17]. who achieved a maximum conversion of $\sim 40 \%$ for $x=0.375$, after calcination at $950^{\circ} \mathrm{C} / 4 \mathrm{~h}$ followed by heat rreatment at $1040^{\circ} \mathrm{C} / 4 \mathrm{~h}$. For the case of undoped $\mathrm{BaAl}_{2} \mathrm{Si}_{2} \mathrm{O}_{8}$. it can be seen that the conversion fraction is increased from $\sim 12$ to $\sim 62 \%$ by increasing temperature from 1100 to $1200^{\circ} \mathrm{C}$.

These results show that the optimum conditions to achieve full Hexacelsian to Celsian conversion appear to involve the addition of a suitable amount of $\mathrm{SrCO}_{3}$ to the initial mixture of $\mathrm{CFA}, \mathrm{Al}_{2} \mathrm{O}_{3}, \mathrm{SiO}_{2}$ and $\mathrm{BaCO}_{3}$ employed in the present work. in order to have a $\mathrm{SrO}$ concentration in the range of $0.25 \leq x \leq 0.75$ in the materials thennally rreated at $1200^{\circ} \mathrm{C} /$ $5 \mathrm{~h}$. However, the most recommended addition level within the mentioned range will ultimately depend on how it influences other properties of the materials. such as liquidus temperature and thermal expansion coefficient. which are two of the most important properties when structural applications at high temperature are envisaged. Bansal et al. [13] reported only a small variation in both properties as a function of $\mathrm{SrO}$ content, for $\mathrm{SrO}$-containing $\mathrm{BaAl}_{2} \mathrm{Si}_{2} \mathrm{O}_{8}$ glasses. However. Fu et al. [17] found, for materials synthesized by the solid-state reaction route, that the average thermal expansion coefficient decreased with increasing SrO content, from $\sim 16 \times 10^{-6} / \mathrm{C}^{\circ}$ for $\mathrm{BaAl}_{2} \mathrm{Si}_{2} \mathrm{O}_{8}$ with no added $\mathrm{SrO}$, to a minimum value of $\sim 7 \times 10^{-6} /{ }^{\circ} \mathrm{C}$ for SrO concentrations of $0.25 \leq x \leq 0.475$, in the temperature range of $25-400^{\circ} \mathrm{C}$. These authors recommended an optimum SrO addition level of $x=0.375$. Based on these results, as well as on those obtained in the present work. the optimum SrO level recommended by us is $0.25 \leq x \leq 0.375$.

\subsection{Rietveld refinement of synthesized materials}

Before starting the Rietveld refinements, the inscrumental broadening of the diffractometer was determined with the aid of a $\mathrm{LaB}_{6}$ NIST standard with a known narrow crystallite size distribution. The peak shape model employed was the one of Thompson-Cox-Hastings (TCA). For asymmetry corrections, the model of Bérar-Baldinozzi [35] was employed. The background was fitted to a 20 degree polynomial. With these premises, the Pawley refinements were initiated setting free the zero shift of the goniometer $2 \theta^{\circ}$ scale, asymmetry. crystallite size, lattice strain, cell parameters and background coefficients. The Cagliotti coefficients $(u, v, w)$, and $X$ and $Y$ coordinates of the TCA peak shape were always kept constant since they determine the instrumental broadening. After a few cycles, the refinements converged. In a second stage, the Rietveld refinements were initiated using as starting values the ones found in the first stage. The occupancy of large $\mathrm{Ba} / \mathrm{Sr}$ cations were first set free, on top of the parameters refined by the
Table 8

Agreement factor, cell parameters $(\AA)$ and occupancies after the Rietveld refinements. The exrors of cell parameters are \pm 0.004 . The exrors associated to the occupancy are \pm 0.03 .

\begin{tabular}{lllllll}
\hline Sample code & $R_{\text {stp }}$ & $a$ & $b$ & $c$ & $\beta$ & Ba occ. \\
\hline BAS 2 & 7.82 & 8.636 & 13.054 & 7.205 & 115.040 & 0.938 \\
B7S2 & 6.60 & 8.581 & 13.039 & 7.190 & 115.088 & 0.853 \\
B6S3 & 5.67 & 8.543 & 13.011 & 7.171 & 115.103 & 0.827 \\
B5S5 & 5.59 & 8.516 & 13.009 & 7.166 & 115.134 & 0.792 \\
B2S7 & 6.07 & 8.444 & 12.986 & 7.143 & 115.196 & 0.708 \\
SAS & 7.81 & 8.374 & 12.955 & 7.119 & 115.302 & 0.616 \\
\hline
\end{tabular}

Table 9

Crystallographic data for the studied compositions, according to the corresponding JCPDS cards [38].

\begin{tabular}{|c|c|c|c|c|}
\hline Sample code & $a$ & $b$ & $c$ & $\beta$ \\
\hline $\mathrm{BAS}_{2}$ & 8.641 & 13.04 & 7.203 & 115.07 \\
\hline B7S2 & 8.58 & 1.303 & 7.189 & 115.15 \\
\hline B5S5 & 8.51 & 13.01 & 7.169 & 115.13 \\
\hline $\mathrm{B} 2 \mathrm{~S} 7$ & 8.45 & 12.99 & 7.151 & 115.23 \\
\hline SAS & 8.393 & 12.97 & 7.132 & 115.38 \\
\hline
\end{tabular}

Pawley method [36], doing then the same with the atomic positional parameters, the preferential orientation parameters according to the model of Rietveld-Toraya [37]. and. finally, the global isotropic Debye-Waller factor. The statistics of the diffraction pattern due to the presence of other phases and the limitations of the instrument did not allow the determination of individual isotropic Debye-Waller factors. When attempted, some of the ionic species atcained meaningless physical values. The rest of the refined parameters reached acceptable values, including the atomic coordinates of all ion species.

The most relevant parameters found after the Rietveld refinements are shown in Table 8 . All cell parameters are very similar to those reported in the JCPDS cards [38] for $\mathrm{SrAl}_{2} \mathrm{Si}_{2} \mathrm{O}_{8}$ and $\mathrm{BaAl}_{2} \mathrm{Si}_{2} \mathrm{O}_{8}$ (with and without $\mathrm{Sr}$ content). as shown in Table 9 . This implies that the materials synthesized in the present work were chemically and stnicturally similar to those obtained from reagent-grade raw materials. whose cell parameters are reported in the JCPDS cards.

Some minor amounts of $\mathrm{Ti}$ and $\mathrm{Fe}$ were present in the analyzed samples, most likely as $\mathrm{Ti}_{1}^{4+}$ and $\mathrm{Fe}^{3+}$ partially substituting the small $\mathrm{Al}^{3+}$ and $\mathrm{Si}^{4+}$ ions. Since X-rays do not allow to discriminate between ionic species such as $\mathrm{Si}^{4+}, \mathrm{Al}^{3+}$. $\mathrm{Fe}^{+3}$ and $\mathrm{Ti}^{4+}$, it was assumed as a good approximation that the population of $\mathrm{Ba}^{2+}$ found for Celsian without $\mathrm{Sr}$ could be used to determine the small $\mathrm{M}^{3+} / \mathrm{M}^{4+}$ cation ratio, simply from a balance of charges. For the rest of the Celsian samples, it was supposed that the $\mathrm{M}^{3+} / \mathrm{M}^{4+}$ ratio was the same and therefore the number of vacancies at that site was considered to be constant. With this hypothesis in mind, the $\mathrm{Ba} / \mathrm{Sr}$ proportions were escimated for the whole series.

For the occupancy analysis of large cations in site 4(i) only $\mathrm{Ba}$ ions were considered. since the Rietveld module of MS4 does not allow the presence of two different species in the same site. To calculate the $\mathrm{Ba} / \mathrm{Sr}$ ratio for the Sr-containing specimens, the scattering factors for $\mathrm{Ba}^{2+}$ and $\mathrm{Sr}^{2+}$ were 
Table 10

Proportion of barium in the specimens as a function of the refined occupancy (p).

\begin{tabular}{lllllll}
\hline$p$ & 0.938 & 0.853 & 0.827 & 0.792 & 0.708 & 0.616 \\
\hline$z(x+z)$ & 1.0 & 0.73 & 0.64 & 0.53 & 0.26 & -0.03 \\
\hline
\end{tabular}

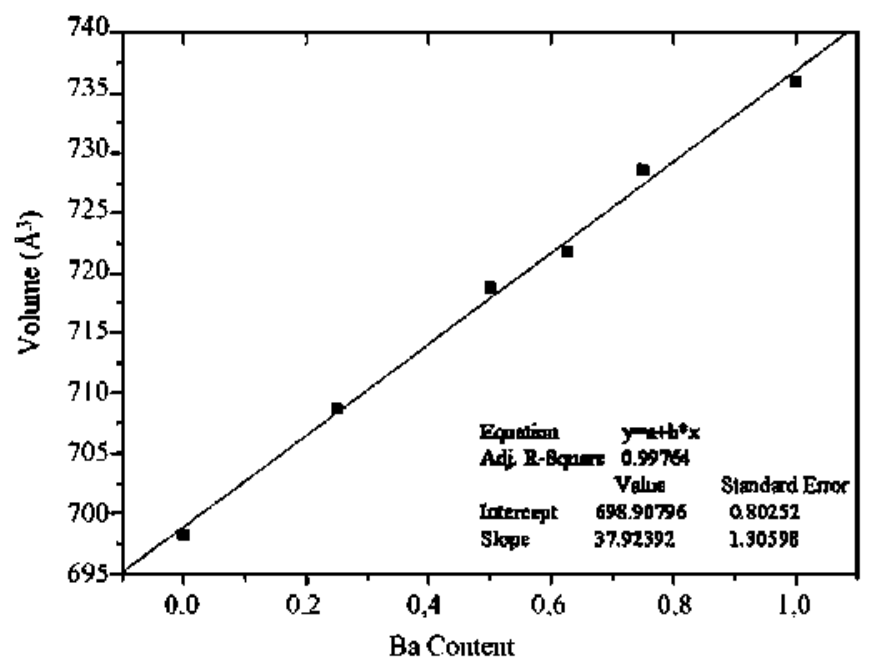

Fig. 7. Variation of cell volume of Celsian samples analyzed as a function of Ba content. A siraight line was fitted and its statistic parameters are shown as an inset.

simply considered to be proportional to their respective number of electrons $(Z-2)$. Although this is not a completely rigorous assumption, it is a good approximation, bearing in mind the precision of the results attained. In this part of the work. the general formula for the synthesized materials was considered to be $\mathrm{Ba}_{z} \mathrm{Sr}_{x}\left(\mathrm{Al}_{1-y} \mathrm{Si}_{y}\right)_{4} \mathrm{O}_{8}$. where $z=1-x$ and $y \sim 0.53$. according to the literature. Therefore, the expression governing the proportion of Ba present in every analyzed specimen can be written as:

$\frac{z}{x+z}=\frac{\left(z_{\mathrm{BA}}-1\right)(p / 0.938)-z_{\mathrm{Sr}}-2}{z_{\mathrm{BA}}-z_{\mathrm{Sr}}}=\frac{3 p}{0.938}-2$

$p$ is the occupancy found for $\mathrm{Ba}$ in the Rietveld refinement for the specimen without Sr. A summary of the proportions found can be seen in Table 10.

The theoretical $\mathrm{Ba} / \mathrm{Sr}$ ratios for the analyzed samples are: $1: 0 ; 0.75: 0.25 ; 0.625: 0.375 ; 0.5: 0.5 ; 0.25: 0.75$ and $0: 1$. Thus. Table 10 shows that the calculated proportions of Ba agree very well with the expected values.

The direct approach of finding the $\mathrm{Ba} / \mathrm{Sr}$ occupancy was tested vs. the more indirect one of correlation with the crystal cell size. Indeed, if the content of small cacions in sites $\mathrm{T} 1$ and T2 remains constant, the cell parameters should vary in a linear fashion as a function of $\mathrm{Ba}$ or $\mathrm{Sr}$ content. In Fig. 7, the trend of cell variation can be appreciated. The cell volume has been plotted against $\mathrm{Ba}$ content. The linear increase of the cell volume with composition. from $\mathrm{SrAl}_{2} \mathrm{Si}_{2} \mathrm{O}_{8}$ to $\mathrm{BaAl}_{2} \mathrm{Si}_{2} \mathrm{O}_{8}$. indicates that Vegard's rule is obeyed. These results also confirm the formation of $\mathrm{Ba}_{1-\lambda} \mathrm{Sr}_{x} \mathrm{Al}_{2} \mathrm{Si}_{2} \mathrm{O}_{8}$ solid solutions over the entire concentration range $0 \leq x \leq 1$ [24].

\section{Conclusions}

Monoclinic (Celsian) and hexagonal (Hexacelsian) $\mathrm{Ba}_{1-\lambda} \mathrm{Sr}^{-}$ ${ }_{2} \mathrm{Al}_{2} \mathrm{Si}_{2} \mathrm{O}_{8}$ solid solutions were synthesized by using Coal Fly Ash (CFA) as main raw material, employing a simple one-step solid-state reaction process. The $\mathrm{Ba}_{0.625} \mathrm{Sr}_{0.375} \mathrm{Al}_{2} \mathrm{Si}_{2} \mathrm{O}_{8}$ composition showed the largest Hexacelsian to Celsian conversion $(96 \%)$ at $1100 \mathrm{C} / 5 \mathrm{~h}$, while full conversion was achieved at $1200^{\circ} \mathrm{C} / 5 \mathrm{~h}$ for materials with $\mathrm{SrO}$ contents in the range of $0.25 \leq x \leq 0.75$. An optimum SrO level of $0.25 \leq x \leq 0.375$ was recommended for stabilization of Celsian at the latter temperature, based on the effect of $\mathrm{SrO}$ on the liquidus temperature and thenmal expansion coefficient of these materials, reported by other researchers. Chemical analyses and Rietveld refinements showed that the synthesized materials were chemically and structurally similar to analogous macerials obcained from reagent-grade powders in previously published literature. The easy stabilization of Celsian at a relatively low temperature and short time, when compared to previously published data, can be attributed to the joint contribution of two main factors: (a) presence of $\mathrm{Al}_{2} \mathrm{O}_{3}$ and $\mathrm{SiO}_{2}$. already chemically combined forming mullite and an amorphous phase, together with a large content of free $\mathrm{SiO}_{2}$ in the CFA employed; this resulted in a reaction path leading to the fomation of transient barium silicates $\left(\mathrm{BaSiO}_{3}, \mathrm{Ba}_{2} \mathrm{SiO}_{4}\right.$ and $\mathrm{BaSi}_{2} \mathrm{O}_{5}$ ) in the cemperature range of $850-1100^{\circ} \mathrm{C}$; the fomation of barium aluminates was also detected at temperatures higher than $900^{\circ} \mathrm{C}$; all of this led in tum to an easy formation of Hexacelsian; (b) a likely synergistic mineralizing effect of impurities present in the CFA. particularly $\mathrm{CaO}$ and $\mathrm{TiO}_{2}$, which could act in combination with the added SrO. greatly facilitating the Hexacelsian to Celsian conversion. Lastly, thermodynamics calculations were used to validate the decailed model for the reaction sintering mechanism. It can be appreciaced that the theoretical predictions agree with the sequential appearance of phases. Namely, $\Delta G$ computations for the fonmation of $\mathrm{BaAl}_{2} \mathrm{Si}_{2} \mathrm{O}_{8}$. $\mathrm{BaSiO}_{3}, \mathrm{Ba}_{2} \mathrm{SiO}_{4}, \mathrm{Ba}_{2} \mathrm{Si}_{3} \mathrm{O}_{8}, \mathrm{BaSi}_{2} \mathrm{O}_{5}$ and $\mathrm{BaAl}_{2} \mathrm{O}_{4}$ confirm the much lower $\Delta G$ value for $\mathrm{BaAl}_{2} \mathrm{Si}_{2} \mathrm{O}_{8}$ in the whole range of temperatures considered. Consequently, its appearance as the first phase during reaction is fully justified.

\section{Acknowledgements}

The authors express their gratitude to CONACYT. México, for the financial support provided for the realization of this work (project no. P47257-Y, under the responsibility of J.L.C.), and for a scholarship granted to D.L.G. to cary out his Ph.D. studies at Cinvestav-Saltillo as well as a research stay at Instituto de Cerámica y Vidrio (ICV), Madrid. Spain. The work in Spain was carried out in the frame of project MEC MAT2006-13480 C02-01. The authors wish to acknowledge the assistance of Dra. P. Recio (ICV) in the course of the XRD analyses. Many thanks are also given 
to the personnel of the "José López Portillo" power plant for supplying the employed CFA.

\section{References}

[1] X.-D. Zhang, K.H. Sandhage, H.L. Fraser, Synthesis of $\mathrm{BaAl}_{2} \mathrm{Si}_{2} \mathrm{O}_{8}$ from solid $\mathrm{Ba}-\mathrm{Al}-\mathrm{Al}_{2} \mathrm{O}_{3}-\mathrm{SiO}_{2}$ precursors. II. TEM analyses of phase evolution. Journal of the American Ceramic Society 81 (11) (1998) 2983-2997.

[2] R.A. McCauley, Polymonthisin and dielecinc eleciric properties of Baand Sr-containing feldspars, Joumal of Materials Science 35 (15) (2000) 3939-3942.

[3] J.S. Moya Corral. G. Verduch, The solid solution of silica in celsian, Transactions and Joumal of the British Ceramic Society 77 (2) (1978) $40-44$.

[4] V.S.R. Murhy, M.H. Lewis, Matrix crystallizalion and interface structure in SiC-Celsian composites. Transactions and Journal of the British Ceramic Society 89 (5) (1990) 173-174.

[5] N.P. Bansal, Strong and tough Hi-Nicalon-fiber-reinforced celsian matrix composites, Joumal of the American Ceramic Society 80 (9) (1997) 2407-2409.

[6] K.N. Lee, D.S. Fox. J.I. Eldridge. D. Zhu, R.C. Robinson. N.P. Bansal, R.A. Miller, Upper temperature limit of environmental barrier coatings based on mullite and BSAS, Journal of the American Ceramic Society 86 (8) (2003) 1299-1306.

[7] B. Yoshiki. K. Matsumolo. High-lemperature moditication of barium feldspar. Journal of the American Ceramic Society 80 (9) (1997) 2021-2029.

[8] H.C. Lin, W.R. Foster, Studies in the system $\mathrm{BaO} \cdot \mathrm{Al}_{2} \mathrm{O}_{3} \cdot \mathrm{SiO}_{2}$. I, The polymorphism of celsian, American Mineralogist 53 (1-2) (1968) 134-144.

[9] N. Frety, A. Taylor, M.H. Lewis, Microstncture and crystallization behavior of sol-gel derived $1 / 2 \mathrm{SrO}-1 / 2 \mathrm{BaO}-\mathrm{Al}_{2} \mathrm{O}_{3}-2 \mathrm{SiO}_{2}$ glass-ceramic, Journal of Non-Crystalline Solids 195 (1-2) (1996) 28-37.

[10] Y. Kobayashi, Transformation kinetics from hexacelsian to celsian for powders having uniform particle size, Ceramics International 27 (2) (2001) 179-184.

[11] M.C. Guillem Villar. C. Guillem Monzonis, J.A. Navarro, Reactions between kaolin and barium cartonate: influence of mineralizers. 1. Qualitative study, Transactions and Jounal of the British Ceramic Society 82 (2) (1983) 69-72.

[12] K.T. Lee. P.B. Aswath. Role of mineralizers on the hexacelsian to celsian transformation in the barium aluminosilicate $\left(\mathrm{BAS}_{2}\right)$ system. Materials Science and Engineering A 352 (1-2) (2003) 1-7.

[13] N.P. Bansal, M.J. Hyatt, C.H. Drummond III, Crystallization and propertjes of Sr-Ba aluminositicate glass-ceramic malnces. Ceramic Engineering and Science Proceedings 12 (7-8) (1991) 1222-1234.

[14] S.S. Amritphale, A. Anshul, N. Chandra, N. Ramakrishnan, Development of celsian ceramics from fly ash useful for $\mathrm{X}$-ray radiation-shielding application, Journal of the European Ceranic Society 27 (16) (2007) $4639-4647$.

[15] L.D. Hulett, A.J. Weinberger, K.J. Northcutt, M. Fergusone, Chemical species in fy ash from coal-burning power plant. Science 210 (4476) (1980) 1356-1358.

[16] K.-T. Lee. P.B. Aswalh, Enhanced production of celsian barium aluminosilicates by a three-step firing technique. Materials Chemistry and Physics 71 (1) (2001) 47-52.

[17] Y.-P. Fu, C.-C. Chang, C.-H. Lin. T.-S. Chin. Solid-slate synthesis of ceramics in the $\mathrm{BaO}-\mathrm{SrO}_{\mathrm{O}} \mathrm{Al}_{2} \mathrm{O}_{3}-\mathrm{SiO}_{2}$ system, Ceranics Intemational 30 (1) (2004) 41-45.
[18] Accelrys Materials Sudio v. 40. Accelrys, Cambridge. CB4 OWN. UK. 2005.

[19] M.G. Skellern, R.A. Howie, E.E. Lachowski, J.M.S. Skakle, Bariumdeficient celsian. $\mathrm{Ba}_{1-x} \mathrm{Al}_{2-2,} \mathrm{Si}_{2+2} \mathrm{O}_{8}(x=0.20$ or 0.06$)$, Acta Crystal lographica Section C: Crystal Structure Comınunications 59 (2) (2003) i1 1-i14.

[20] Outokumpu Research Oy, Pori. Finland Outokumpu HSC Chemistry for Windows Vetsion 1.10, 1993.

[21] S. Gomes. M. Francois, Characterization of mullite in silicoaluminous fy ash by XRD, TEM. and Si MAS NMR, Cement and Concrete Research 30 (2) (2000) 175-181.

[22] L.D Hulett, A.J. Weinberger, Some etching studies of the microstructure and composition of large aluminosilicate particles in fy ash from coalburning power plants. Environtnental Science and Technology 14 (8) (1980) 965-970.

[23] I.G. Talmy, D.A. Haught, Celsian-based $\left(\mathrm{BaO} \cdot \mathrm{Al}_{2} \mathrm{O}_{3} \cdot \mathrm{SiO}_{2}\right)$ ceramics as candidates for radomes, in: Proceedings of the 14th Conference on Metal. Carbon and Ceramic Composites. NASA Conference Publicalion No. 3097, Part I, 1990, pp. 227-238.

[24] N.P. Bansal, Solid state synthesis and properties of monoclinic celsian, Journal of Materials Science 33 (19) (1998) 471 1-4715.

[25] M.M. Krzinanc. M. Valant, D. Suyorov. The synthesis and microwave dielectric properies of $\mathrm{Sr}_{x} \mathrm{Ba}_{1-x} \mathrm{Al}_{2} \mathrm{Si}_{2} \mathrm{O}_{8}$ and $\mathrm{Ca}_{3} \mathrm{Ba}_{\mathrm{I}_{-}}, \mathrm{Al}_{2} \mathrm{Si}_{2} \mathrm{O}_{8}$ ceramics, Journal of the European Ceramic Society 27 (2-3) (2007) 1181-1185.

[26] N.P. Bansal. Celsian formation in fiber-reinforced barium aluminosilicate glass-ceramic mairix composites, Materials Science and Engineering A 342 (1-2) (2003) 23-27.

[27] Y. Kobayashi, M. Inagaki, Preparation of reactive Sr-celsian powders by solid-stale reaction and their sintering. Journal of the European Ceramic Society 24 (2) (2004) 399-404.

[28] J.S. Moya, G. Verduch, Estudio de la reacción entre el caolín y el carbonato de bario. Boletín de la Sociedad Española de Cerámica y Vidrio 15 (6) (1976) 379-381.

[29] I. Arvanitidis. D. Sichen, S. Seetharaman, A sudy of the themal decomposition of $\mathrm{BaCO}_{3}$, Metallurgical and Materials Transactions $\mathrm{B}$ 27 (3) (1996) 409-416.

[30] A.M. Mailra, K. Foger. Identilication of solid solutions and other phases in strontium and barium catalysts containing oxides of magnesium. aluminum or silicon as additive. II. Catalyst characterization, Applied Catalysis A: General 114 (1) (1994) 83-107.

[31] K.-T. Lee, P.B. Aswath, Synthesis of hexacelsian barium aluminosilicate by a solid-state process, Journal of the Anerican Ceranic Society 83 (12) (2000) 2907-2912.

[32] A. Bandyopadhyay, P.B. Aswath, A phase transformation study in the $\mathrm{BaO} \cdot \mathrm{Al}_{2} \mathrm{O}_{3} \cdot \mathrm{SiO}_{2}(\mathrm{BAS})-\mathrm{Si}_{3} \mathrm{~N}_{4}$ system, Journal of Materials Research 10 (12) (1995) 3143-3148.

[33] E.M. Levin, H.F. McMurdie, Phase Diagram for Ceramists, vol. 3. The American Ceramic Society, Westerville, OH, 1975, p. 220.

[34] K.-T. Lee, P.B. Aswath. Kinetics of the hexacelsian to celsian transformation in barium aluminosilicales doped with $\mathrm{CaO}$. International Journal of Inorganic Materials 3 (7) (2001) 687-692.

[35] J. Baldinozzi, J.F. Bérar, Modeling of line-shape asymmetry in powder diffraction, Joumal of Applied Crystallography 26 (1) (1993) 128-134.

[36] G.S. Pawley. Unit-cell refinement from powder diffraction scans, Joumal of Applied Crystallography 14 (6) (1981) 357-361.

[37] H. Toraya, F. Marumo, Preferred orientation correction in powder palternfitting, Mineralogical Journal 10 (5) (1981) 211-221.

[38] JCPDS Cards: \#381450 for monoclinic $\mathrm{BaAl}_{2} \mathrm{Si}_{2} \mathrm{O}_{8}$, \# 381451 for $\mathrm{Ba}_{0.75} \mathrm{SI}_{0.25} \mathrm{Al}_{2} \mathrm{Si}_{2} \mathrm{O}_{8}$, \# 381452 for $\mathrm{Ba}_{0.5} \mathrm{SI}_{0.5} \mathrm{Al}_{2} \mathrm{Si}_{2} \mathrm{O}_{8}$. \# 381453 for $\mathrm{Ba}_{0 . .5} \mathrm{Sr}_{0.75} \mathrm{Al}_{2} \mathrm{Si}_{2} \mathrm{O}_{8}$. \#381454 for $\mathrm{SrAl}_{2} \mathrm{Si}_{2} \mathrm{O}_{8}$. 